\title{
Carbon isotope variability across the Ediacaran Yangtze platform in South China: Implications for a large surface-to-deep ocean $\delta{ }^{13} \mathrm{C}$ gradient
}

\author{
Ganqing Jiang ${ }^{\mathrm{a}, *}$, Alan J. Kaufman ${ }^{\mathrm{b}}$, Nicholas Christie-Blick ${ }^{\mathrm{c}}$, \\ Shihong Zhang ${ }^{\mathrm{d}}$, Huaichun $\mathrm{Wu}^{\mathrm{e}}$

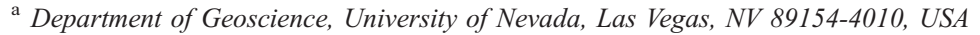 \\ b Department of Geology, University of Maryland, College Park, MD 20742-4211, USA \\ ${ }^{\mathrm{c}}$ Department of Earth and Environmental Sciences and Lamont-Doherty Earth Observatory of Columbia University, \\ Palisades, NY 10964-8000, USA \\ ${ }^{\mathrm{d}}$ School of Earth Sciences and Resources, China University of Geosciences, Beijing 100083, China \\ e School of Marine Sciences, China University of Geosciences, Beijing 100083, China
}

Received 2 February 2007; received in revised form 25 May 2007; accepted 3 July 2007

Available online 17 July 2007

Editor: M.L. Delaney

\begin{abstract}
New isotope data obtained from relatively conformable, carbonate-rich strata of the Ediacaran Yangtze platform in South China reveal substantial $\delta^{13} \mathrm{C}$ variability. In platform sections, four negative $\delta^{13} \mathrm{C}$ anomalies with a nadir down to $\leq-8 \%$ (PDB) are present in the interval between the cap carbonate level ( $\sim 635 \mathrm{Ma})$ and the Precambrian/Cambrian boundary $(\sim 542 \mathrm{Ma})$, while in slope and basinal sections, $\delta^{13} \mathrm{C}$ values are negative through the entire Doushantuo Formation $(\sim 635-551 \mathrm{Ma})$. If these $\delta^{13} \mathrm{C}$ values are close to their primary seawater signature, they imply a strong $(\geq 10 \%)$ surface-to-deep ocean $\delta^{13} \mathrm{C}$ gradient that is consistent with long-term deep ocean anoxia and the presence of a large dissolved organic carbon (DOC) reservoir. The two prominent negative $\delta^{13} \mathrm{C}$ excursions within the Doushantuo Formation above the cap carbonate level are associated with shoaling and local exposure of the platform. The anomalies may thus record remineralization of a large oceanic DOC pool via sulfate reduction that transferred ${ }^{13} \mathrm{C}$-depleted carbon from the oceanic DOC reservoir to the surface ocean during regression. Inconsistencies in Ediacaran $\delta^{13} \mathrm{C}$ profiles globally and variations in South China in particular highlight the need for further evaluation of local departures in $\delta^{13} \mathrm{C}$ from an inferred average seawater signature.
\end{abstract}

(C) 2007 Elsevier B.V. All rights reserved.

Keywords: Neoproterozoic; Ediacaran; carbon isotopes; Doushantuo Formation; Dengying Formation; Yangtze platform; South China

* Corresponding author. Tel.: +1 702895 2708; fax: +1 702895 4064 .

E-mail address: jiangg@unlv.nevada.edu (G. Jiang).

\section{Introduction}

Recent carbon isotope studies of Ediacaran successions $(\sim 635-542 \mathrm{Ma})$ reveal unusually negative $\delta^{13} \mathrm{C}$ anomalies with magnitudes from $\geq+5 \%$ down to 

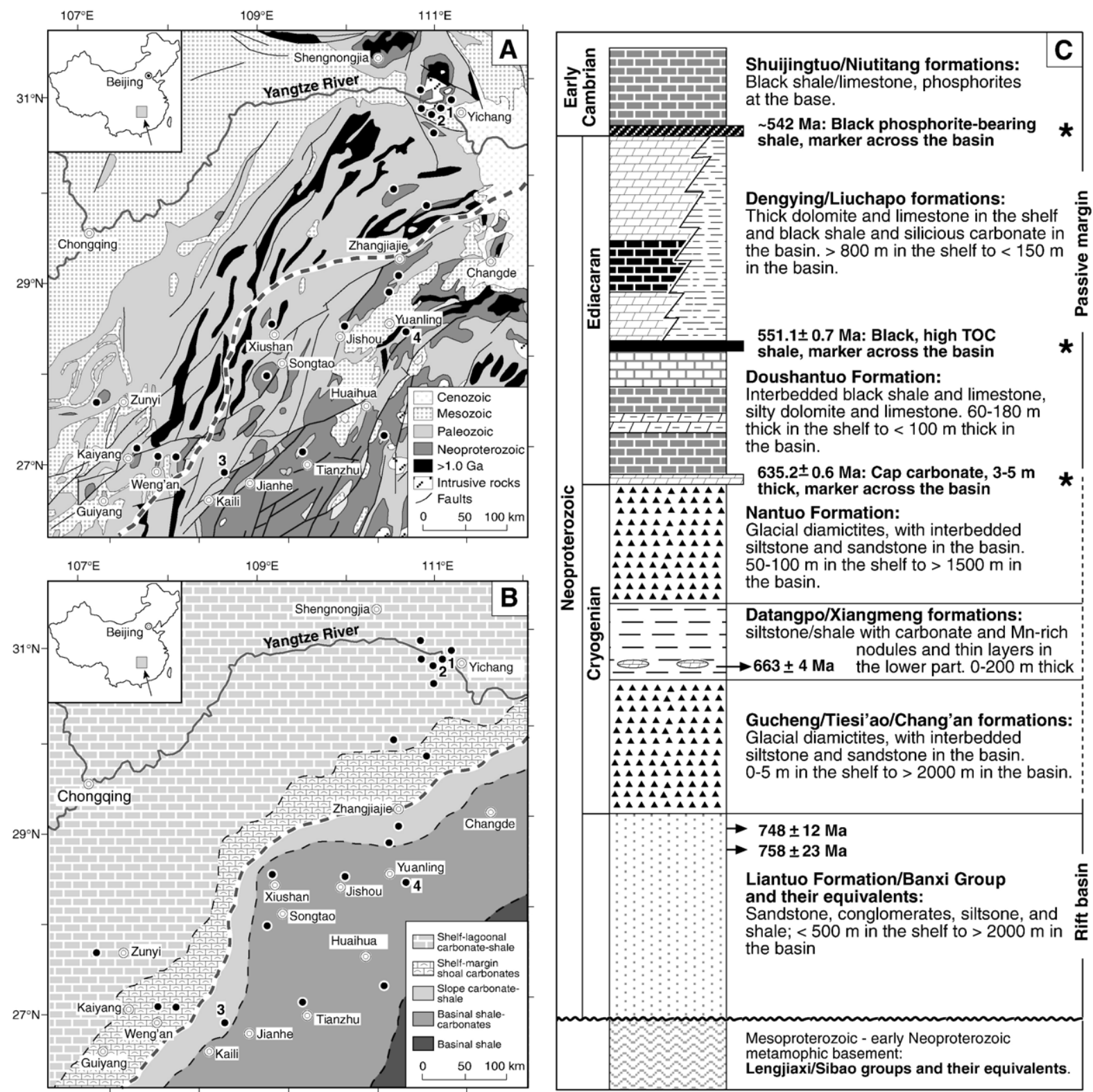

Fig. 1. (A) Simplified geological map showing exposure of Neoproterozoic strata in the Yangtze platform of South China and position of the Ediacaran carbonate platform margin (coarse dashed line). (B) Paleogeographic reconstruction of the Yangtze platform during deposition of the middle and upper Doushantuo Formation. Filled circles mark sections measured for sedimentological analyses and numbers 1 to 4 indicate sections sampled for isotope analyses (Figs. 2-5). (C) Summary of the Neoproterozoic stratigraphy of the Yangtze platform. Age data, from oldest to youngest, are cited from Yin et al. (2003), Ma et al. (1984), Zhou et al. (2004), and Condon et al. (2005). Asterisks indicate stratigraphic markers used for regional correlation across the Yangtze platform.

$\leq-12 \%$ (e.g., Calver, 2000; Corsetti and Kaufman, 2003; Halverson et al., 2005; Melezhik et al., 2005; Fike et al., 2006; Le Guerroue et al., 2006; Kaufman et al., 2006, 2007). Although the age, number, magnitude and global correlation of these prominent $\delta^{13} \mathrm{C}$ anomalies remain controversial, they have been interpreted as recording unusual oceanographic events that may have been critical for the evolution of early animal life (e.g., Fike et al., 2006).

A particular point related to these $\delta^{13} \mathrm{C}$ anomalies is the implication for long-term ocean stratification and a large surface-to-deep ocean $\delta^{13} \mathrm{C}$ gradient. If large 
Ediacaran negative $\delta^{13} \mathrm{C}$ anomalies $(\leq-12 \%)$ reflect ocean chemistry, they are incompatible with mantlederived $\mathrm{CO}_{2}$ as the carbon source (e.g., the 'snowball' Earth hypothesis; Hoffman et al., 1998; Hoffman and Schrag, 2002). The apparently long duration (millions of years; Fike et al., 2006; Le Guerroue et al., 2006) of these anomalies also challenges interpretations related to methane hydrate destabilization (Kennedy et al., 2001; Jiang et al., 2003a, 2006a,b) or upwelling and mixing of ${ }^{13} \mathrm{C}$-depleted deep-ocean seawater during deglaciation (e.g., Kaufman et al., 1991; Grotzinger and Knoll, 1995; Knoll et al., 1996; Shields, 2005). One possible, yet not adequately tested model is the remineralization of a large dissolved organic carbon (DOC) reservoir stored in the ocean (Rothman et al., 2003; Fike et al., 2006). Considering the lack of zooplankton fecal pellets and siliceous skeletons in the Precambrian (e.g., Logan et al., 1995), organic matter would have a much longer residence time in the ocean water column and a larger DOC reservoir (10 to 100 times of the modern ocean; Rothman et al., 2003) would be expected. However, a large oceanic DOC reservoir, if it existed, would require significant deep ocean anoxia or euxinia to retard DOC oxidation. Sulfate concentration documented from Ediacaran shallow-water carbonates (e.g., Shields et al., 2004; Goldberg et al., 2005; Hurtgen et al., 2005) suggests that at least episodically the surface ocean $\mathrm{SO}_{4}^{2-}$ may have reached near to modern levels $(\sim 28 \mathrm{mM})$. Elevated sulfate abundances in an anoxic, DOC-rich ocean would have promoted water column sulfate reduction and the plausible development of a strong depth gradient in carbon isotope compositions. Documentation of such a gradient for the Ediacaran Period has been difficult owing to the preferential preservation of platform deposits relative to those in slope and basinal facies. In South China, preservation of both shallow and deep water environments of this age provides us with an opportunity to test these hypotheses and to examine $\delta^{13} \mathrm{C}$ variability in a platform-to-basin transect.

Preliminary isotope studies from the Ediacaran Yangtze platform $(\sim 635-542 \mathrm{Ma})$ in South China have been published in various forms (Lambert et al., 1987; Li et al., 1999a; Yang et al., 1999; Shen and Schidlowski, 2000; Shen, 2002; Wang et al., 2002a,b; Chu et al., 2003; Jiang et al., 2003a; Condon et al., 2005; Zhang et al., 2005; Guo et al., 2006; see Zhou and Xiao, 2007, for a review). Yet none of these studies was conducted at high resolution and there were no systematic comparisons between platform and basinal sections. Here we report high resolution carbon isotope data obtained from multiple sections across the
Ediacaran Yangtze platform and discuss implications and uncertainties for the origin of the negative Ediacaran $\delta^{13} \mathrm{C}$ anomalies.

\section{The Ediacaran Yangtze platform}

The Ediacaran Yangtze platform (Fig. 1) developed over a Neoproterozoic rifted continental margin that is inferred to have initiated along the southeastern side of the Yangtze block at $\sim 800 \mathrm{Ma}$ (Li et al., 1999b; Wang and Li, 2003; Jiang et al., 2003b, 2006a). A passive margin setting has been inferred for post-glacial Ediacaran carbonate rocks (Jiang et al., 2003b; Wang and Li, 2003), although with unresolved questions about the timing of the rift to post-rift transition and an apparent increase in the rate of tectonic subsidence at $\sim 550 \mathrm{Ma}$ (Condon et al., 2005; Zhang et al., 2005).

The Neoproterozoic succession of the Yangtze platform is composed of three main intervals (Fig. 1C): (1) pre-glacial siliciclastic rocks assigned to the Liantuo Formation in the platform and Banxi Group in the basin, (2) two Cryogenian glacial diamictite intervals (Gucheng/Tiesi'ao/Chang'an formations and Nantuo Formation) separated by a manganese-bearing siltstone/shale unit (Datangpo/Xiangmeng formations), and (3) post-glacial Ediacaran marine carbonates and shales assigned to the Doushantuo and Dengying/ Liuchapo formations. Compared to their global equivalents, these strata have among the best age constraints, especially for the Ediacaran Period. Important $\mathrm{U}-\mathrm{Pb}$ zircon ages (Fig. 1C) include (1) $748 \pm 12 \mathrm{Ma}$ (Ma et al., 1984 ) and $758 \pm 23 \mathrm{Ma}$ (Yin et al., 2003) from the upper Liantuo Formation and Banxi Group, respectively, (2) $663 \pm 4 \mathrm{Ma}$ from the interglacial Datangpo Formation (Zhou et al., 2004), (3) 635.2 $\pm 0.6 \mathrm{Ma}$ and 632.5 \pm $0.5 \mathrm{Ma}$ within and above the cap carbonate (Condon et al., 2005), (4) 551.1 \pm 0.7 Ma near the Doushantuo/ Dengying boundary (Condon et al., 2005; Zhang et al., 2005), and (5) an inferred $\sim 542 \mathrm{Ma}$ age for the Precambrian/Cambrian boundary on the basis of small shelly fossils, a $538.2 \pm 1.5 \mathrm{Ma}$ age above the boundary (Jenkins et al., 2002), and a comparison with biozones and dating of the boundary in other successions globally (Grotzinger et al., 1995; Amthor et al., 2003).

In addition, the Ediacaran interval in the Yangtze platform contains the most fossiliferous strata of its age (Fig. 2). Abundant multicellular algae and large processbearing acanthomorph acritarchs have been reported from the Doushantuo Formation in the Yangtze Gorges area (e.g., Zhang et al., 1998; Xiao et al., 2002; Xiao, 2004; Zhou and Xiao, 2007; Zhou et al., 2007). A few taxa of acanthomorphic acritarchs make their first 
appearance just meters above the basal Doushantuo cap carbonate (Xiao, 2004; Zhou et al., 2007). Possible animal embryos and microscopic animals were also reported (Yin et al., 2007), especially in the upper Doushantuo Formation at Weng'an (Xiao et al., 1998, 2007; Zhou et al., 2007). In the black shale unit near the

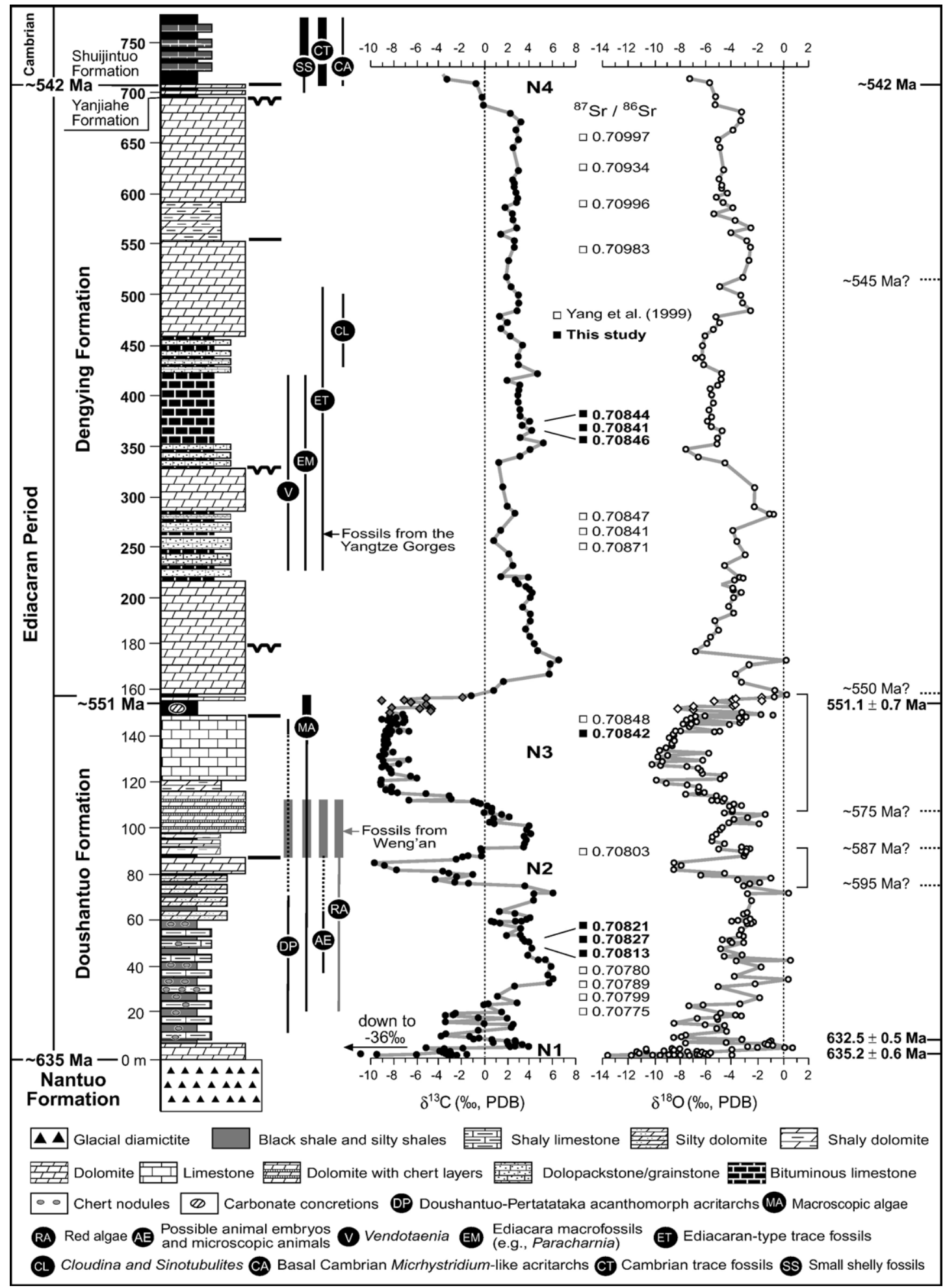


Doushantuo/Dengying boundary, abundant and diverse macroscopic carbonaceous compression fossils have been reported; a few of them have been interpreted as non-bilaterian animals or tubular organisms (Xiao et al., 2002). Classic Ediacara assemblage fossils, macroscopic bilaterians represented by trace fossils, and biomineralizing animals such as Sinotubulites and Cloudina are reported from the Dengying Formation and its regional equivalents (Hua et al., 2005; Xiao et al., 2005).

Three well defined markers (Fig. 1C), the basal Doushantuo cap carbonate ( $635 \mathrm{Ma})$, the organic-rich (TOC locally $>10 \%$ ) black shale at Doushantuo/ Dengying boundary $(\sim 551 \mathrm{Ma})$, and phosphoritebearing black shale at the Precambrian/Cambrian boundary $(\sim 542 \mathrm{Ma})$, are traceable from the platform to the basin (Jiang et al., 2006a,b). These markers serve as important tie-points for correlation between sections, except in the Weng'an area where the shale at the Doushantuo/Dengying contact is missing at a karstic unconformity.

Our paleogeographic reconstruction of the southeastfacing Ediacaran Yangtze platform (Fig. 1B) is based on the following evidence: (1) glaciogenic diamictite units underlying the Doushantuo cap carbonate thicken in that direction (Jiang et al., 2003b, 2006a), from $<100 \mathrm{~m}$ in the shelf to $>1500 \mathrm{~m}$ in the basin; (2) the post-glacial carbonate-rich strata are characterized by a platform edge characterized by an intraclastic-oolitic and stromatolite-rich shoal complex (cf. Jiang et al., 2003c) that thins basinward and changes facies into lagoonal deposits of the platform interior (Jiang et al., 2003b), and (3) slump blocks, debris-flow breccias and turbidites are abundant in the slope facies south of the inferred platform margin (Jiang et al., 2003b, 2006a).

\section{Isotope data from the Ediacaran Yangtze platform}

For this study, 607 samples were collected from four measured sections, two located on the platform near Yichang, one on the slope, and one in the basin (Fig. 1A and B). After petrographic characterization, $0.5-5 \mathrm{mg}$ of powder was drilled from the finest-grained portion of each sample (e.g., Kaufman and Knoll, 1995). Isotope analyses were done at the Stable Isotope Lab at the University of Colorado, Boulder, the University of Maryland Geochemical Laboratories, and the University of California, Riverside. Results are reported using the standard $\delta$-notation compared to PDB. Precision of internal standards $(n=62)$ for both $\delta^{13} \mathrm{C}$ and $\delta^{18} \mathrm{O}$ is better than $0.1 \%$. Seven carefully chosen pure limestone samples were analyzed for ${ }^{87} \mathrm{Sr} /{ }^{86} \mathrm{Sr}$ ratios. About $2 \mathrm{mg}$ of powdered sample was pre-leached with $0.5 \mathrm{M}$ ammonium hydroxide $(\mathrm{pH} \sim 8.2)$ and dissolved in $0.5 \mathrm{M}$ ultrapure acetic acid. Strontium was separated from the solutions with $\mathrm{Sr} \mathrm{Spec}$ resin and then loaded with $\mathrm{TaO}$ on degassed $\mathrm{Re}$ filaments for isotopic analysis on the VG Sector 54 thermal ionization mass spectrometer at the University of Maryland Geochemical Laboratories. The average of the NBS 987 standards $(n=4)$ run during the two analytical sessions was $0.710242 \pm 0.000011$.

\subsection{Platform sections}

Isotope data from the most complete section in the Yangtze Gorges area (loc. 1 in Fig. 1A and B; Table A1) reveal four prominent negative $\delta^{13} \mathrm{C}$ anomalies: at the Doushantuo cap carbonate level as well as in the middle and upper Doushantuo Formation, and at the Precambrian-Cambrian boundary (N1 through N4 in Fig. 2). Most $\delta^{13} \mathrm{C}$ values for the 5-m-thick cap carbonate (N1) are from -2 to $-6 \%$, but extremely negative $\delta^{13} \mathrm{C}$ values as low as $-36 \%$ were obtained from cements in cavities and fracture fills (Table A1). Within $20 \mathrm{~m}$ above the cap carbonate, $\delta^{13} \mathrm{C}$ values are highly variable, ranging from +4 to $-4 \%$ at meter scales. The likelihood that these bed-to-bed variations are primary is not high; we thus interpret many of these samples as diagenetically altered (cf. Kaufman and Knoll, 1995; Jiang et al., 2003a). Above an interval with positive $\delta^{13} \mathrm{C}$ values $(+1$ to $+6 \%$ ) from $20 \mathrm{~m}$ to $75 \mathrm{~m}$, a negative $\delta^{13} \mathrm{C}$ anomaly (N2) with a nadir down to $-9 \%$ encompasses a $15-\mathrm{m}$ thick interval from $75 \mathrm{~m}$ to $90 \mathrm{~m} . \delta^{13} \mathrm{C}$ values rise abruptly between $90 \mathrm{~m}$ and $100 \mathrm{~m}$ from near 0 to $+4 \%$, and then decrease again into a 50-m-thick interval in the uppermost Doushantuo Formation with persistently

Fig. 2. Carbon, strontium, and oxygen isotope data for the Ediacaran Doushantuo and Dengying formations measured from Jiunongwan-Shipai section in the Yangtze Gorge area (loc. 1 in Fig. 1A and B). Fossil contents are summarized from Zhang et al. (1998), Xiao et al. (2002), Xiao (2004), Xiao et al. (2005), Zhou et al. (2007), and Zhou and Xiao (2007). U-Pb ages in bold font are from Condon et al. (2005), except the PrecambrianCambrian boundary, which is inferred from comparison of fossil contents with other successions in Namibia (Grotzinger et al., 1995) and Oman (Amthor et al., 2003), and the age of 538.2 \pm 1.5 Ma from the Lower Cambrian Meishucun section in Yunnan Province, South China (Jenkins et al., 2002). Inferred ages with question markers are interpolated from available age data (see Table A1 for details). Notice the change of scale in stratigraphic column at $200 \mathrm{~m}$. 
negative $\delta^{13} \mathrm{C}$ values from -7 to $-9 \%$ (N3). Persistently positive $\delta^{13} \mathrm{C}$ values from +2 to $+5 \%$ characterize the 550-m-thick Dengying Formation, with values as high as $+6 \%$ a few meters above the Doushantuo/ Dengying boundary $(\sim 551 \mathrm{Ma})$, and a transition down to $-3 \%$ at the Precambrian-Cambrian boundary (N4).

The three negative $\delta^{13} \mathrm{C}$ anomalies (N1-N3) from the Doushantuo Formation are found in both platform sections (Fig. 3; Table A1), which are $6 \mathrm{~km}$ apart. The considerable isotopic variability in the cap lithofacies, with $\delta^{13} \mathrm{C}$ values as low as $-41 \%$, is consistent with previous reports from the succession (Jiang et al., 2006a,b). The stratigraphic interval encompassed by the middle (N2) and upper (N3) Doushantuo negative anomalies varies slightly, but the overall pattern of fall and rise is similar.

In both sections, $\delta^{18} \mathrm{O}$ values are variable, ranging from 0 to $-10 \%$, and down to $-15 \%$ for some samples of the cap carbonate (Fig. 4A and B). They also broadly covary with carbon isotopes, especially at the N2 level. Because oxygen is a major component of sedimentary
A

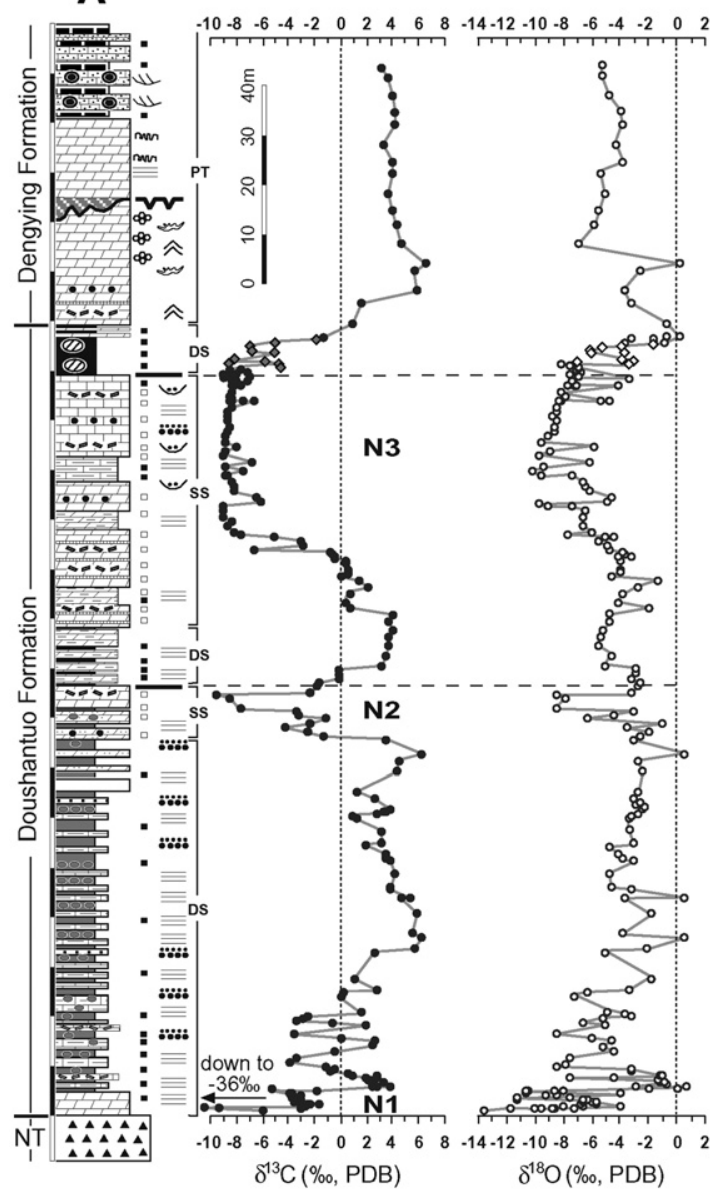

B

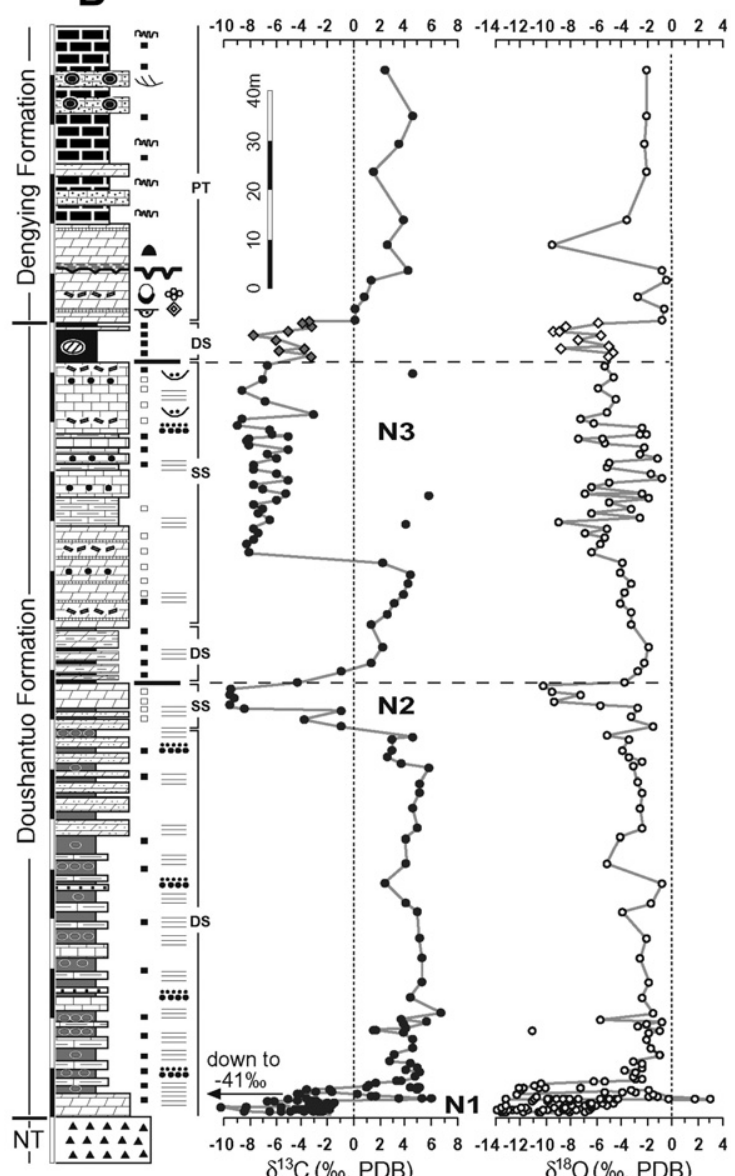

- Chert nodules $\delta^{13} \mathrm{C}(\%, \mathrm{PDB})$

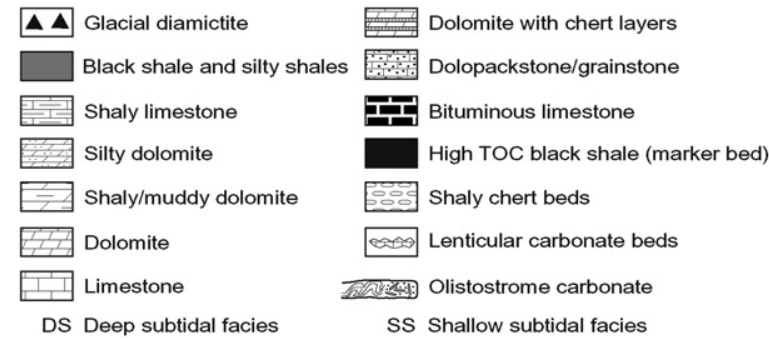

(1) Calcite concretion

- Disseminated pyrites

Secondary pyrites

- Ooids

- Peloids

-- Intraclasts

- Pisolites

- Gypsum casts

Brecciation

(P) Phosphorite

- Thrombolites

PT Peritidal facies

Fig. 3. Integrated sedimentological and carbon and oxygen isotope profiles of the Doushantuo Formation from two platform sections (loc. 1 and 2 in Fig. 1A and B). Notice that negative $\delta^{13} \mathrm{C}$ anomalies (N2 and $\mathrm{N} 3$ ) are largely below a flooding surface. 

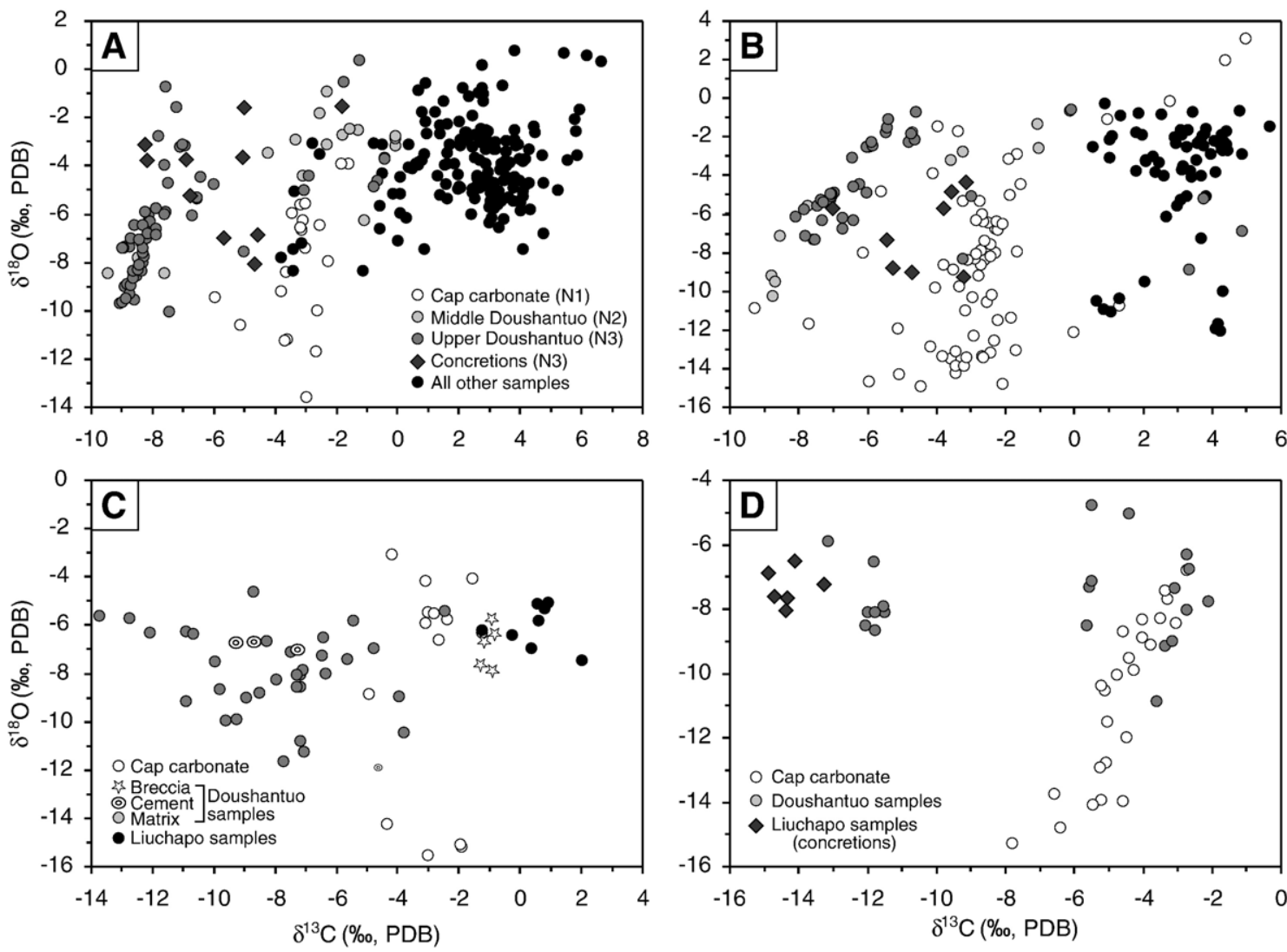

Fig. 4. Cross-plots of carbon and oxygen isotopes. (A) Platform section A (Fig. 2). (B) Platform section B (Fig. 3B). (C) Slope section (Fig. 5A). (D) Basinal section (Fig. 5B).

fluids, the likelihood that these $\delta^{18} \mathrm{O}$ values record a primary seawater signature is low (cf. Banner and Hanson, 1990; Kaufman and Knoll, 1995).

Strontium isotopes (Table A2) from the lower and middle Doushantuo Formation range from 0.7078 to 0.7083 , rising to 0.7084 in the uppermost Doushantuo Formation (at the top of N3), and to 0.7085 in the middle Dengying Formation (Fig. 2). Absolute ${ }^{87} \mathrm{Sr} /{ }^{86} \mathrm{Sr}$ values and the upward-increasing trend are consistent with those obtained by Yang et al. (1999) from the Yangtze Gorge area and are in agreement with the overall trend obtained from other Ediacaran successions (e.g., Derry et al., 1992; Kaufman et al., 1993, 1997; Jacobsen and Kaufman, 1999).

Sedimentological and petrographic analyses indicate that no major unconformity is present within the Doushantuo Formation in either section. However, two large-scale deep subtidal to shallow subtidal cycles are recognized (Fig. 3). The top of each cycle is marked by an abrupt lithofacies change from carbonate-rich facies (grainstone and packstone) to pyrite-rich black shale with minor carbonate. Considering their regional persistence, the abrupt lithofacies changes are interpreted as major flooding surfaces (Jiang et al., 2003b). Deep subtidal facies are characterized by interbedded shale, siltstone and micritic carbonates, with minor intraclastic or peloidal packstone and wackestone interbeds. The absence of grainstone and cross-stratification and presence of abundant parallel lamination and normal grading suggest deposition below fairweather wave base, and in part from storm-generated turbidity currents. Shallow subtidal facies are interpreted on the basis of intraclastic or peloidal grainstone and scoured bases. The $\mathrm{N} 2$ and $\mathrm{N} 3$ negative $\delta^{13} \mathrm{C}$ anomalies reach minimum values within shoaling facies below flooding surfaces and return to positive values above flooding surfaces.

Given consistent lithology, conformability and $\mathrm{U}-\mathrm{Pb}$ ages of $635.2 \pm 0.6 \mathrm{Ma}, 632.5 \pm 0.5 \mathrm{Ma}$, and $551.1 \pm$ $0.7 \mathrm{Ma}$ from the base and top of the Doushantuo Formation (Condon et al., 2005), a simple age interpolation (cf. Saylor et al., 1998; Halverson et al., 2005) suggests that the two post-cap carbonate negative $\delta^{13} \mathrm{C}$ anomalies correspond approximately with the 


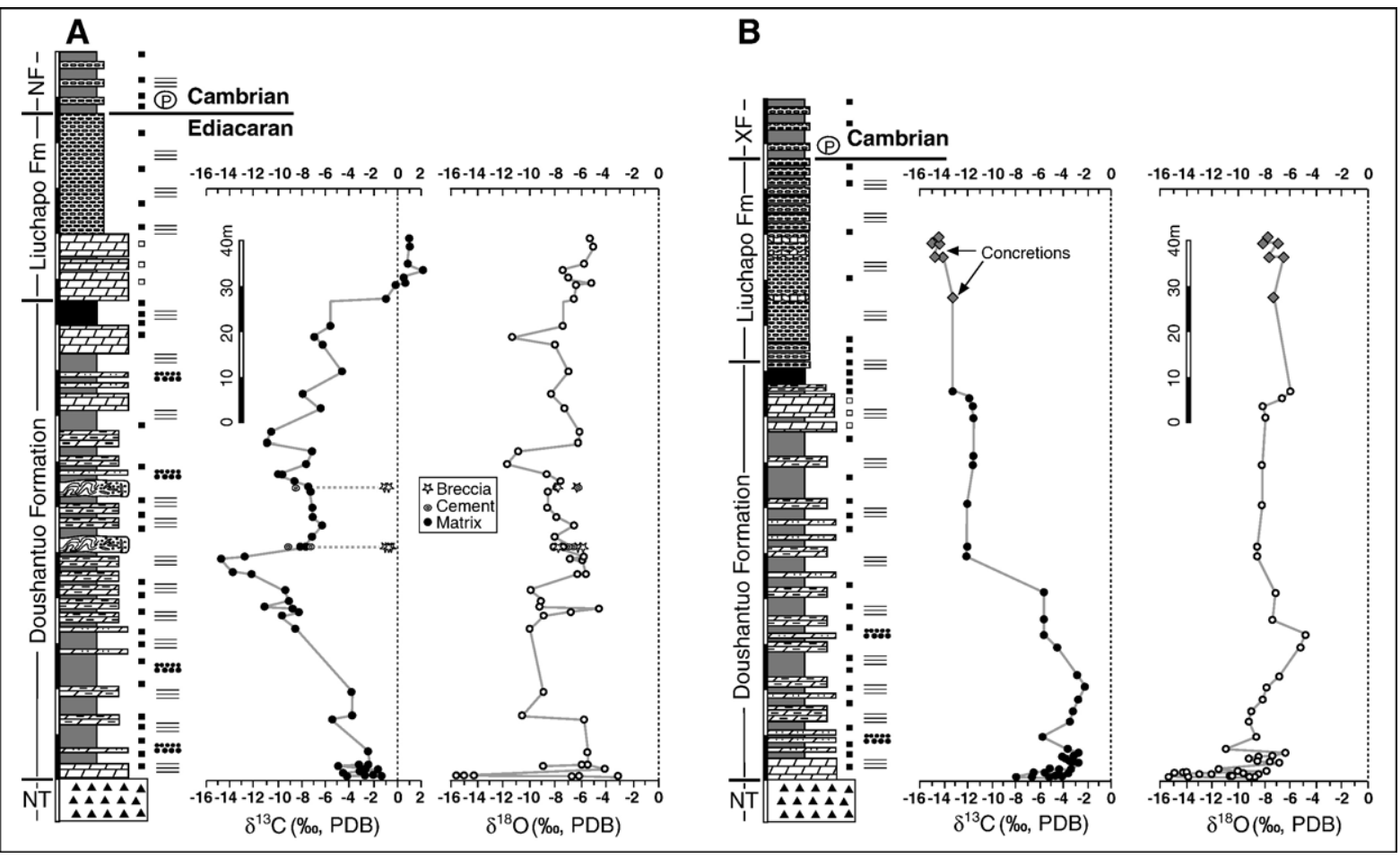

Fig. 5. Carbon and oxygen isotope profiles of the Doushantuo Formation from slope (A) and basinal (B) sections (loc. 3 and 4 in Fig. 1A and B). See Fig. 3 for an explanation of symbols.

spans $\sim 595-587 \mathrm{Ma}$ and $\sim 575-550 \mathrm{Ma}$, respectively (Fig. 2; Table A1). We recognize the inherent uncertainties in such estimates related to variations in depositional rate, paleobathymetry, and compaction. However, we suspect that the two anomalies encompass spans of time greater than the $<10^{5}$ years that has been estimated for the cap carbonates (Hoffman et al., 1998; Kennedy et al., 2001; Shields, 2005).

\subsection{Slope and basinal sections}

In the slope section (Fig. $5 \mathrm{~A}$ ), $\delta^{13} \mathrm{C}$ values from the cap carbonate range from -2 to $-5 \%$, similar to the range obtained from the dolomicrite/microcrystalline dolomite samples from the same cap carbonate in the platform sections (Fig. 3). In contrast to those sections, however, negative $\delta^{13} \mathrm{C}$ values continue upwards through the entire Doushantuo Formation, with a nadir down to $-14 \%$. Negative $\delta^{13} \mathrm{C}$ values return to positive $(\sim+2 \%)$ immediately above the Doushantuo/Liuchapo boundary, where a 3.5-m-thick, pyrite-rich, high-TOC black shale has been traditionally considered as the equivalent to the black shale unit in the platform (Figs. 2 and 3). In the middle of the Doushantuo Formation, samples from two breccia layers (carbonate debris flows) reveal different $\delta^{13} \mathrm{C}$ values in matrix, isopachous cement and breccia clast samples. $\delta^{13} \mathrm{C}$ values in breccia clasts range from -0.7 to $-1.2 \%$, while isopachous cements and micritic matrix range from -7 to $-9 \%$. The $\sim 7 \%$ difference between clasts and cement may reflect isotopic differences between the source of the breccias (the platform margin to upper slope) and the site of deposition (lower slope), although further work is needed to test this interpretation.

In the basinal section (Fig. 5B), cap carbonate samples have $\delta^{13} \mathrm{C}$ values between -3 and $-8 \%$. Negative $\delta^{13} \mathrm{C}$ values continue through the entire Doushantuo Formation, ranging from -2 to $-5.5 \%$ for the lower Doushantuo Formation, from -5.5 to $-12 \%$ in the middle of that unit, and from -11 to $-13 \%$ upsection across the Doushantuo/Liuchapo boundary. The lowest values $(-14 \%)$ are observed in lenticular limestone beds (and concretions) of the Lichapo Formation.

Absolute $\delta^{18} \mathrm{O}$ values from both slope and basinal sections are relatively stable, mostly ranging from -4 to $-10 \%$, but samples from the cap carbonate have highly depleted $\delta^{18} \mathrm{O}$ values down to $-15 \%$ (Fig. $4 \mathrm{C}$ and $\mathrm{D}$ ). No obvious covariation between $\delta^{13} \mathrm{C}$ and $\delta^{18} \mathrm{O}$ is observed for the slope section (Fig. 4C). For the basinal section, a 
clear $\delta^{13} \mathrm{C}-\delta^{18} \mathrm{O}$ covariation for the cap carbonate samples is observed (Fig. 4B), but a narrow $\delta^{18} \mathrm{O}$ range $(-4$ to $-8 \%)$ is recorded in the remaining samples.

Using the cap carbonate and black shale units at the Doushantuo/Dengying boundary as markers, the carbon isotope profiles can be correlated from the platform to the basin (Fig. 6). The phosphorite-bearing black shale that contains Early Cambrian fossils also supports this correlation.

\section{Chemostratigraphic and paleoceanographic implications}

\subsection{A potential reference $\delta^{13} C$ record for the Ediacaran Period}

If $\delta^{13} \mathrm{C}$ values from the platform sections are close to their primary signature, as many have argued for the Neoproterozoic succession in South China (e.g., Yang et al., 1999; Wang et al., 2002a) and other successions globally (e.g., Kaufman et al., 1991; Kaufman and Knoll,
1995; Corsetti and Kaufman, 2003; Halverson et al., 2005; Le Guerroue et al., 2006), the relatively conformable and carbonate-rich strata of the Doushantuo and Dengying formations may provide the most complete and best-dated $\delta^{13} \mathrm{C}$ record and thus holds the potential to be a reference section for the Ediacaran Period (Figs. 2 and 7A). From the cap carbonate level $(\sim 635 \mathrm{Ma})$ to the Precambrian/ Cambrian boundary $(\sim 542 \mathrm{Ma})$, four negative $\delta^{13} \mathrm{C}$ anomalies (N1 through N4) are noted, each with a nadir down to $\leq-8 \%$ (see Zhou et al., 1997; Shen and Schidlowski, 2000; for additional data points at the Precambrian/Cambrian boundary). The ages of anomalies at the cap carbonate level $(\mathrm{N} 1 ; \sim 635 \mathrm{Ma})$, the Doushantuo/ Dengying boundary (N2; $551 \mathrm{Ma}$ ), and the Precambrian/ Cambrian boundary (N4; $542 \mathrm{Ma}$ ) are well constrained. The age of the $\delta^{13} \mathrm{C}$ excursion in the middle of the Doushantuo Formation (N2) is less certain, but likely $\sim 595 \mathrm{Ma}$ (Fig. 2, Table A1). The $\delta^{13} \mathrm{C}$ record of the 550-m-thick Dengying Formation $(\sim 551 \mathrm{Ma}$ to $\sim 542 \mathrm{Ma}$ ) is very stable, with $\delta^{13} \mathrm{C}$ values from $+2 \%$ to $+5 \%$ and an average close to $+3 \%$.

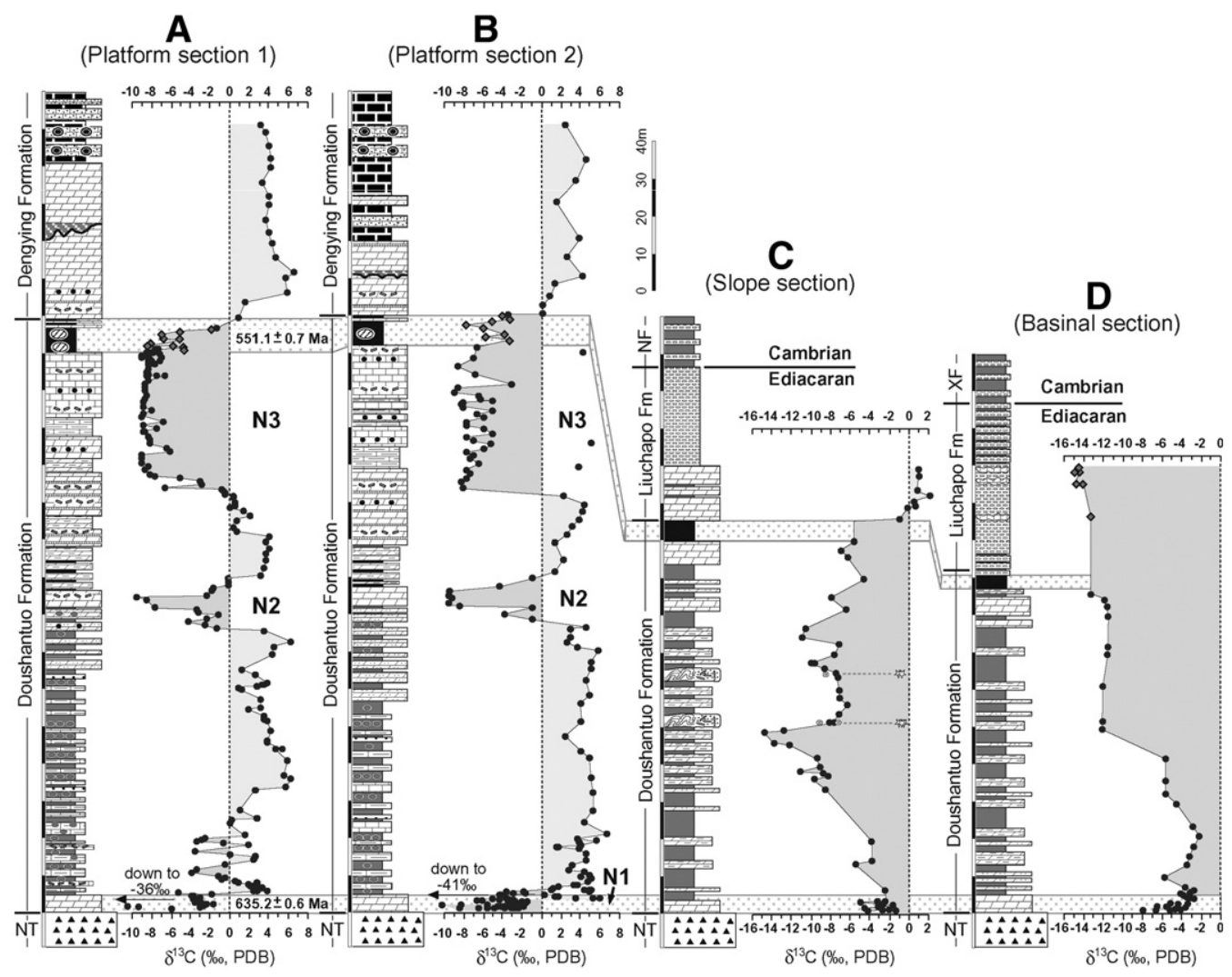

Fig. 6. Comparison of carbon isotope profiles from platform to basinal sections. The cap carbonate ( $\sim 635 \mathrm{Ma})$ and the organic-rich black shale $(\sim 551 \mathrm{Ma})$ are used as the datum for platform-to-basin correlation, and phosphorite-bearing black shales with early Cambrian fossils near the Precambrian-Cambrian boundary provided additional information for this correlation. 


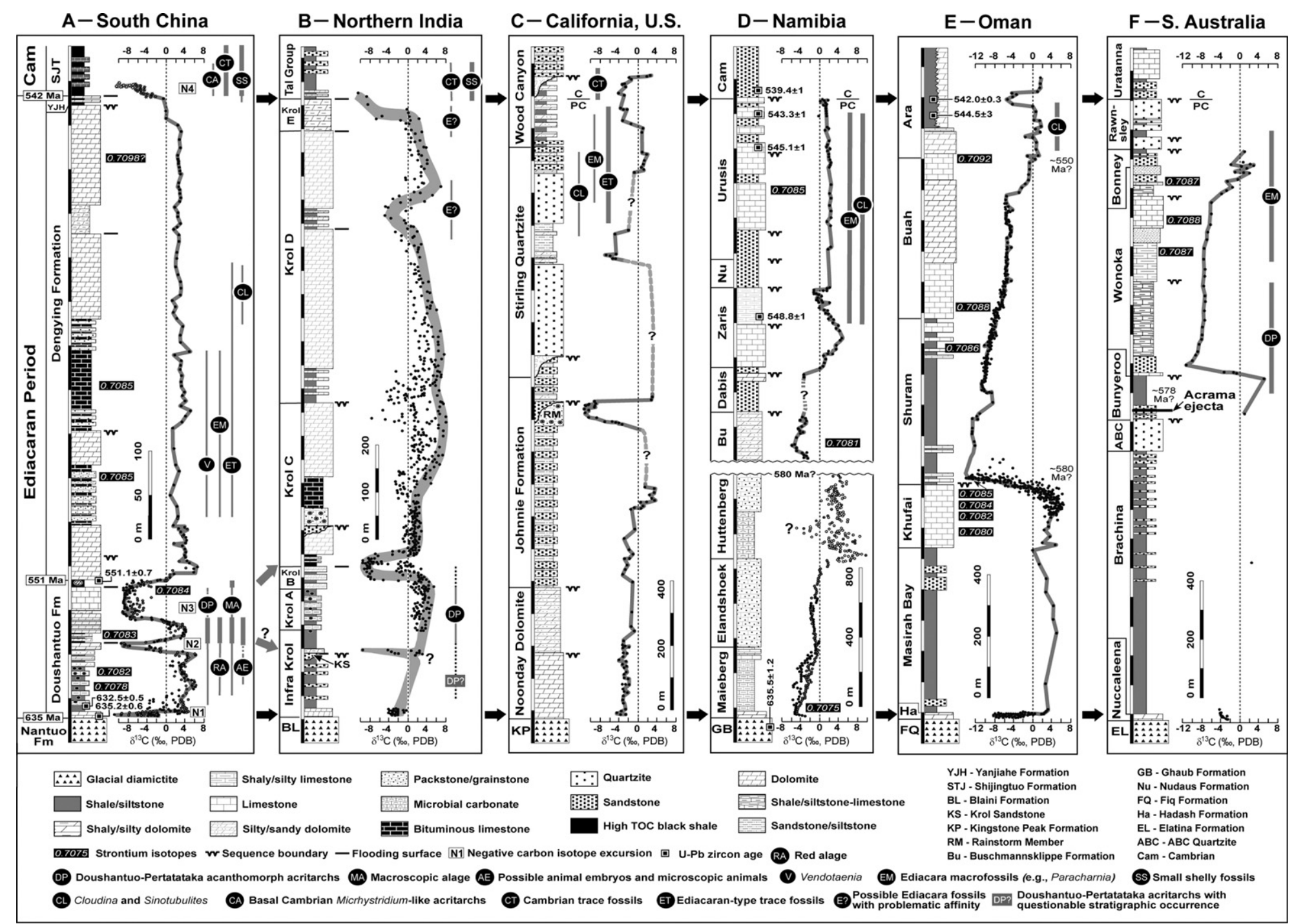

Fig. 7. The composite sequence and chemostratigraphy of the Ediacaran succession in South China (A) and its comparison with other Ediacaran successions from which negative $\delta^{13} \mathrm{C}$ anomalies have been reported, including (B) northern India (Jiang et al., 2002; Kaufman et al., 2006), (C) eastern California of western US (Corsetti and Kaufman, 2003, 2005; Kaufman et al., 2007), (D) northern and southern Namibia (Grotzinger et al., 1995; Saylor et al., 1998; Halverson et al., 2005), (E) Oman (Fike et al., 2006; Le Guerroue et al., 2006), and (F) the Adelaide rift complex of southern Australia (Christie-Blick et al., 1995; Calver, 2000; Grey, 2005). 


\subsection{Sea-level changes and $\delta^{13} C$ anomalies}

Integrated sedimentological and isotope analyses of the platform sections (Fig. 3) indicate that negative $\delta^{13} \mathrm{C}$ anomalies (N2 and N3) encompass abrupt regional stratigraphic discontinuities interpreted as flooding surfaces, with the most negative $\delta^{13} \mathrm{C}$ values below each flooding surface, and a return to positive values in overlying deeper-water deposits. A similar pattern has been observed at the $\mathrm{Krol} \mathrm{C} / \mathrm{Krol} \mathrm{B}$ transition in northern India (Fig. 7B; Jiang et al., 2002; Kaufman et al., 2006), potentially at the top of the Rainstorm Member of the Johnnie Formation in California (Fig. 7C; Corsetti and Kaufman, 2003; Kaufman et al., 2007), at the top of the Dabis and basal Zaris formations in southern Namibia (Fig. 7D; Kaufman et al., 1991; Saylor et al., 1998), and from the pre-Cryogenian Chuar Group ( 770-742 Ma) in the Grand Canyon of the western U.S. (Dehler et al., 2005). Although correlation between these successions is still problematic, it is possible that the observed pattern is a general if not universal one in Ediacaran strata. This is inconsistent with the view from both Marinoan and Sturtian aged cap carbonates where strongly negative $\delta^{13} \mathrm{C}$ anomalies are associated with upwelling during transgression (e.g., Grotzinger and Knoll, 1995; Knoll et al., 1996).

\subsection{A potential Ediacaran surface-to-deep ocean $\delta^{13} C$ gradient}

If our isotope data record close to primary seawater or syndepositional diagenetic signatures, marked differences between the platform, slope and basinal sections (Fig. 6) support the view of a large Ediacaran surface-to-deep ocean $\delta^{13} \mathrm{C}$ gradient. Recognizing potential diagenetic overprints for $\delta^{13} \mathrm{C}$ values $\leq-10 \%$ (cf., Calver, 2000; Melezhik et al., 2005), we choose the $\delta^{13} \mathrm{C}$ values of $-7 \%$ o to $-9 \%$ from isopachous cements surrounding breccias in the slope section (Figs. 4C and 5A) as an approximation of the $\delta^{13} \mathrm{C}$ signature for deep slope and basinal settings, which is consistent with the average $\delta^{13} \mathrm{C}$ value of all samples from these facies. In this case, a $\geq 10 \%$ surfaceto-deep ocean $\delta^{13} \mathrm{C}$ gradient can be inferred during times of positive $\delta^{13} \mathrm{C}$ values in the platform. We recognize that bed-to-bed scale correlation is not possible between sections, however, it is clear that positive $\delta^{13} \mathrm{C}$ values (up to $+6 \%$ ) above the cap carbonate in platform sections contrast with negative values (down to $<-4 \%$ ) above the same cap carbonate in the basin, providing a first-order time-stratigraphic approximation (Fig. 6).

A large $(\geq 10 \%) \quad \delta^{13} \mathrm{C}$ gradient could have been maintained if the deep ocean was anoxic, rich in dissolved organic carbon (DOC), and sulfate was available from continental sources. Remineralization of DOC through sulfate reduction produces bicarbonate $\left(\mathrm{SO}_{4}^{2-}+2 \mathrm{CH}_{2} \mathrm{O} \rightarrow \mathrm{H}_{2} \mathrm{~S}+2 \mathrm{HCO}_{3}^{-}\right)$, which may result in deep basin carbonate precipitation as carbonate crusts, thin cement films captured by falling particles in the water column, or cements during early diagenesis (Fig. 8A).

Such conditions are readily satisfied in restricted basins where a permanent chemocline separates oxic surface water from anoxic deep water. In the Black Sea, an up to $7 \%$ surface-to-deep water $\delta^{13} \mathrm{C}$ gradient has been documented (e.g., Deuser, 1970; Volkov, 2000), and in Framvaren Fjord of southern Norway, bottom water inorganic $\delta^{13} \mathrm{C}$ values are as low as $-19.5 \%$

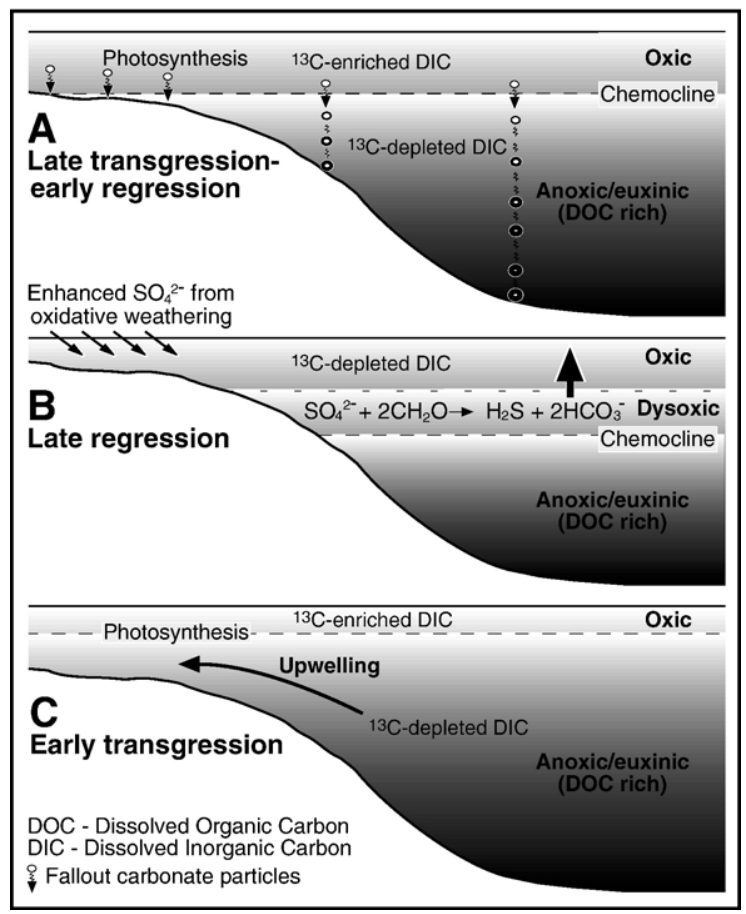

Fig. 8. Schematic diagram interpreting the origin of negative $\delta^{13} \mathrm{C}$ anomalies (N2 and N3 in Figs. 3 and 6). (A) In the existence of a large oceanic DOC reservoir, the ocean was stratified and had a large carbon isotope gradient. While platform facies deposited directly from the surface ocean may have positive $\delta^{13} \mathrm{C}$ values, carbonate particles falling through the water column may capture ${ }^{13} \mathrm{C}$-depleted cements before reaching the seafloor and/or during early diagenesis. (B) During regression, enhanced sulfate input though oxidative weathering (of sulfides) may have facilitated remineralization of the DOC reservoir, transferring ${ }^{13} \mathrm{C}$-depleted carbon from the DOC to DIC reservoir and forming negative $\delta^{13} \mathrm{C}$ anomalies in platform sections. (C) Subsequent upwelling of ${ }^{13} \mathrm{C}$-depleted and sulfide-rich deep water associated with transgression may have caused photic zone anoxia and the rise of chemocline, consistent with pyrite-rich black shales at the top of N2 and N3 (Figs. 3 and 6). 
(Volkov, 2000). A difference of up to 10 to $14 \%$ in $\delta^{13} \mathrm{C}$ between shallow and deep-water carbonates has also been inferred for the Wonoka $\delta^{13} \mathrm{C}$ anomaly in Australia (Calver, 2000) and from isolated Neoproterozoic sections in the Quruqtagh region of northwestern China (Xiao et al., 2004). However, the Ediacaran Yangtze platform extends more than $500 \mathrm{~km}$ and has been inferred to have developed at a passive margin presumably connected to the open ocean. The relatively stable and consistent ${ }^{87} \mathrm{Sr} /{ }^{86} \mathrm{Sr}$ values and trend (Figs. 2 and 7) comparable to other Ediacaran successions also suggest an open-ocean connection. This may imply that widespread Ediacaran deep ocean anoxia and stratification existed in the presence of a large DOC reservoir.

\subsection{The origin of the Ediacaran $\delta^{13} C$ excursions}

The origin of the negative $\delta^{13} \mathrm{C}$ anomaly associated with the cap carbonate has been debated at length, with several competing interpretations. These include the snowball Earth hypothesis (Hoffman et al., 1998; Hoffman and Schrag, 2002), the upwelling hypothesis (Kaufman et al., 1991; Grotzinger and Knoll, 1995; Knoll et al., 1996), the methane hypothesis (Kennedy et al., 2001; Jiang et al., 2003a, 2006a,b), and the 'plumeworld' hypothesis (Shields, 2005). Considering the range of $\delta^{13} \mathrm{C}$ values from $0 \%$ to $-5 \%$ o documented from cap carbonates globally and the estimated short duration $(<1$ million years), each of these hypotheses finds support from one or more lines of evidence. Disagreement about the origin of cap carbonates and their isotope signature will continue until more definitive evidence can be obtained. However, the recognition of a methane-derived isotope signature at multiple sections (Fig. 3) does provide additional support for the influence of methane in the Doushantuo cap carbonate.

More intriguing is the origin of $\delta^{13} \mathrm{C}$ anomalies in the middle and upper Doushantuo Formation (N2 and N3; Figs. 2 and 3) and their possible global equivalents (Fig. 7). Given their larger magnitude and potentially longer duration, most of the existing models proposed for the cap carbonates are not applicable. One possible model involves the remineralization of a large oceanic dissolved organic carbon (DOC) reservoir that was possibly 10-100 times of the modern ocean (Rothman et al., 2003; Fike et al., 2006), or 15,000 to $150,000 \mathrm{Gt}$ of carbon. The presence of ${ }^{13} \mathrm{C}$-depleted deep-water carbonates seems to support this hypothesis. However, what would have triggered the remineralization of the oceanic DOC reservoir and precipitation of ${ }^{13} \mathrm{C}$ depleted carbonates in shallow-water platforms?
One possibility is the increase of oxygen solubility in response to cold climate (Rothman et al., 2003). While this may be applicable to the Sturtian and Marinoan ice ages, it is hard to explain the more profound negative $\delta^{13} \mathrm{C}$ anomalies after the end of Marinoan glaciation. Physical evidence for Gaskiers glaciation around $580 \mathrm{Ma}$ (Bowring et al., 2003) is limited to Avalonia and eastern Laurentia, and only a thin and poorly developed cap carbonate with $\delta^{13} \mathrm{C}$ values down to $-5 \%$ is recognized in Newfoundland (Myrow and Kaufman, 1999). Even if globally cooler temperatures are inferred during the Gaskiers glaciation, downward penetration of atmospheric oxygen, which is thought to have been rising during the Ediacaran (e.g., Derry et al., 1992; Kaufman et al., 1993; Kennedy et al., 2006; Kaufman et al., 2007), might explain the general oxidation of the DOC pool, but it would not account for episodic alkalinity anomalies.

Physical stratigraphic and isotope data from South China and northern India provide another possibility. Based on our recognition that the N2 and N3 events represent times of shoreline regression, it is possible that enhanced weathering increased the sulfate supply to the oceans, triggering the remineralization of the oceanic DOC through sulfate reduction, and the ultimate transfer of ${ }^{13} \mathrm{C}$-depleted carbon from the DOC reservoir to the relatively smaller surface ocean DIC (dissolved inorganic carbon) pool (Fig. 8B). Enhanced sulfate reduction would have lowered the chemocline and facilitated downward oxygen penetration in the oceanic water column, leading to oxidation of the DOC reservoir and providing additional ${ }^{13} \mathrm{C}$-depleted carbon to the ocean and atmosphere. In concert, if atmospheric $\mathrm{O}_{2}$ were rising during this interval, silicate weathering reactions in exposed organic-rich soils might also have supplied ${ }^{13} \mathrm{C}$-depleted alkalinity to marginal marine environments during regressive events (cf. Kaufman et al., 2007).

In both cycles (Fig. 3), negative $\delta^{13} \mathrm{C}$ anomalies reach their minimum values below a flooding surface and return to positive within a few meters above the flooding surface. In addition, the top of the negative $\delta^{13} \mathrm{C}$ anomalies is characterized by pyrite-rich, high TOC shales with unusually high DOP (degree of pyritization) and low $\delta^{97 / 95}$ Mo values (Kendall et al., 2006), suggesting that the top of a $\delta^{13} \mathrm{C}$ anomaly corresponds with a significant anoxic event. This is consistent with a rise of the chemocline and photic zone anoxia/euxinia during times of transgression, as well as upwelling of $\mathrm{H}_{2} \mathrm{~S}$ from deep basins (Fig. 8C; cf. Kump et al., 2005). Such anoxic events, if borne out by additional redox indicators, may be responsible for the 
extinction of the Doushantuo-Pertatataka acritarchs (Figs. 2 and 7A, B, and F).

Carbon isotope anomalies may relate to the non-steady state dynamics of reactive DOC and DIC pools (Rothman et al., 2003). When the DOC reservoir was large enough, a relatively smaller DIC reservoir was more vulnerable to isotope changes. In that case, decoupling of carbonate and organic carbon isotopes would be expected. Only after the excess oceanic DOC was largely remineralized/oxidized and the carbon cycle returned to steady state, would the coupling of $\delta^{13} \mathrm{C}_{\text {carb }}$ and $\delta^{13} \mathrm{C}_{\mathrm{org}}$ occur. This prediction is consistent with recent documentation of decoupled $\delta^{13-}$ $\mathrm{C}_{\text {carb }}$ and $\delta^{13} \mathrm{C}_{\text {org }}$ records from the Ediacaran succession in Oman (Fike et al., 2006). Although more thorough testing is needed, preliminary organic carbon isotopes reported from South China (Li et al., 1999a; Guo et al., 2006) support decoupled $\delta^{13} \mathrm{C}_{\text {carb }}$ and $\delta^{13} \mathrm{C}_{\text {org }}$ values in the Doushantuo Formation. Another prediction of the model is the potential spatial $\delta^{13} \mathrm{C}$ heterogeneity in Ediacaran basins. The depth of the chemocline, which separates the DIC-rich surface ocean from the DOC-rich deep ocean, may vary across sedimentary basins in the presence of a large DOC reservoir, leading to intra-and inter-basinal isotope variations.

\section{Heterogeneity of the global Ediacaran $\delta^{13} \mathrm{C}$ record}

Although strongly negative $\delta^{13} \mathrm{C}$ anomalies have been reported from most Ediacaran successions, existing data display considerable variability (Fig. 7). The stratigraphic succession most similar to that of South China is the Infra Krol Formation and Krol Group from northern India (Fig. 7B; Jiang et al., 2003b; Kaufman et al., 2006). Correlation can be hypothesized between the negative $\delta^{13} \mathrm{C}$ anomaly at the Doushantuo/Dengying boundary (N3) to the Krol C/Krol B transition and, with less confidence, the $\mathrm{N} 2$ anomaly to the middle Infra Krol Formation. However, the negative $\delta^{13} \mathrm{C}$ shift in the upper Krol D does not appear in the Dengying Formation.

Strongly negative $\delta^{13} \mathrm{C}$ values have also been reported from the Ediacaran Rainstorm Member of the Johnnie Formation and the Stirling Quartzite in eastern California of western U.S. (Fig. 7C; Corsetti and Kaufman, 2003; Kaufman et al., 2007). Carbonates in these two intervals are separated by a major unconformity and the rocks are predominantly siliciclastic. So it is uncertain whether the two stratigraphic levels represent one large $\delta^{13} \mathrm{C}$ anomaly (Le Guerroue et al., 2006) or two discrete anomalies (Corsetti and Kaufman, 2003). If the latter suggestion is accepted, correlation of the two anomalies to South China would equate the
Rainstorm Member excursion to the middle Doushantuo Formation (N2) and the Stirling excursion to the upper Doushantuo Formation (N3). Such a correlation, however, raises questions with respect to both the time span and significance of the negative $\delta^{13} \mathrm{C}$ anomaly from the Noonday Dolomite and the lower Johnnie Formation, where negative $\delta^{13} \mathrm{C}$ values encompass a 700 -m-thick interval and two major sequence boundaries (Corsetti and Kaufman, 2005). Alternatively, the Noonday dolomite may be a Sturtian 'cap carbonate', as suggested by the sequence stratigraphic correlation of incisions between the Rainstorm Member and Stirling Quartzite to the interval between the upper Caddy Canyon Quartzite and Mutual Formation in Utah and Idaho, where an Ar-Ar age of $\sim 580$ Ma from volcanics of the Brown's Hole Formation suggests that much of the Mutual Formation (and therefore the Stirling Quartzite) is older than $\sim 580$ Ma (Levy et al., 1994; Christie-Blick, 1997). In this case, the Rainstorm level would be more likely correlative with the Doushantuo cap carbonate $(\mathrm{N} 1 ; \sim 635 \mathrm{Ma})$.

Similar correlation problems exist for the $\delta^{13} \mathrm{C}$ anomalies documented from the succession in Namibia (Fig. 7D). In northern Namibia, negative $\delta^{13} \mathrm{C}$ values above the Ghaub glacial diamictite cover an 800 -m-thick interval (Halverson et al., 2005) that has been interpreted as representing rapid infilling of accommodation created during glaciation (Hoffman et al., 1998; Hoffman and Schrag, 2002). Negative but variable $\delta^{13} \mathrm{C}$ values have been reported from the Hutterberg Formation, which is inferred to predate the Gaskiers glaciation $(\sim 580 \mathrm{Ma}$; Halverson et al., 2005). However, equivalent strata from northeastern Namibia record a prominent positive $\delta^{13} \mathrm{C}$ anomaly (up to $+12 \%$ ) in the Huttenberg Formation, values not recognized in coeval strata anywhere else, though common in strata older than Marinoan glacials (Kaufman et al., 1991). In southern Namibia, negative $\delta^{13} \mathrm{C}$ values have been reported from (1) the post-glacial Buschmannsklippe Formation cap carbonate, (2) the top of the Dabis Formation, which predates $548.8 \pm 1 \mathrm{Ma}$, and (3) the upper Zaris Formation, which postdates 548.8 \pm 1 Ma (Kaufman et al., 1991; Grotzinger et al., 1995; Saylor et al., 1998). Lack of carbonate rocks in the lower Dabis Formation led to uncertainties on whether the negative $\delta^{13} \mathrm{C}$ values from the Buschmannsklippe and Dabis formations belong to a single anomaly (e.g., Saylor et al., 1998; Le Guerroue et al., 2006) or to two separate excursions (Fig. 7D). Based on evidence for hiatuses (sequence boundaries) within the units, two discrete anomalies were deemed likely. Given available age data and a ${ }^{87} \mathrm{Sr} /{ }^{86} \mathrm{Sr}$ value of 0.7081 for the Buschmannsklippe (Kaufman et al., 1997), it is possible that the cap level in 
southern Namibia may be equivalent to the basal Doushantuo cap, but the Dabis anomaly could equate with either N2 or N3 in the Doushantuo.

In successions from Oman (Fig. 7E; Amthor et al., 2003; Fike et al., 2006; Le Guerroue et al., 2006) and Australia (Fig. 7F; Christie-Blick et al., 1995; Calver, 2000; Grey, 2005), negative $\delta^{13} \mathrm{C}$ values were reported from a stratigraphic interval of thickness $>1000 \mathrm{~m}$ and $>500 \mathrm{~m}$, respectively. The large magnitude $\left(\delta^{13} \mathrm{C}\right.$ down to $\leq-12 \%$ ) and expanded thickness make them difficult to match any of the anomalies in south China and other successions. Both absolute $\delta^{13} \mathrm{C}$ values and lithologies of the Shuram and Wonoka formations are similar to those of the slope to basinal facies of the Doushantuo Formation in South China (Fig. 5). Either these negative $\delta^{13} \mathrm{C}$ values record bottom seawater signatures different from shallow water carbonates as discussed above, or they are of diagenetic origin.
With the incompleteness and discrepancy of $\delta^{13} \mathrm{C}$ anomalies from different successions (Fig. 7), it seems premature to use the negative $\delta^{13} \mathrm{C}$ anomalies as time lines for Neoproterozoic stratigraphic correlation, or for blind dating in successions of unknown age. The different magnitudes of the Ediacaran $\delta^{13} \mathrm{C}$ anomalies (with a nadir varying from $-5 \%$ to $\leq-12 \%$; Fig. 7 ) also suggest that some of them must have been subject to significant regional/basinal overprints or diagenetic alteration.

\section{Uncertainties related to the south China data}

Although it is likely that the isotope data from south China represent so far the most complete $\delta^{13} \mathrm{C}$ record for the Ediacaran Period, uncertainties in correlating these negative anomalies globally, the broad $\delta^{13} \mathrm{C}-\delta^{18} \mathrm{O}$ covariation in $\mathrm{N} 2$ and $\mathrm{N} 3$ (Figs. 2 and 3), and more

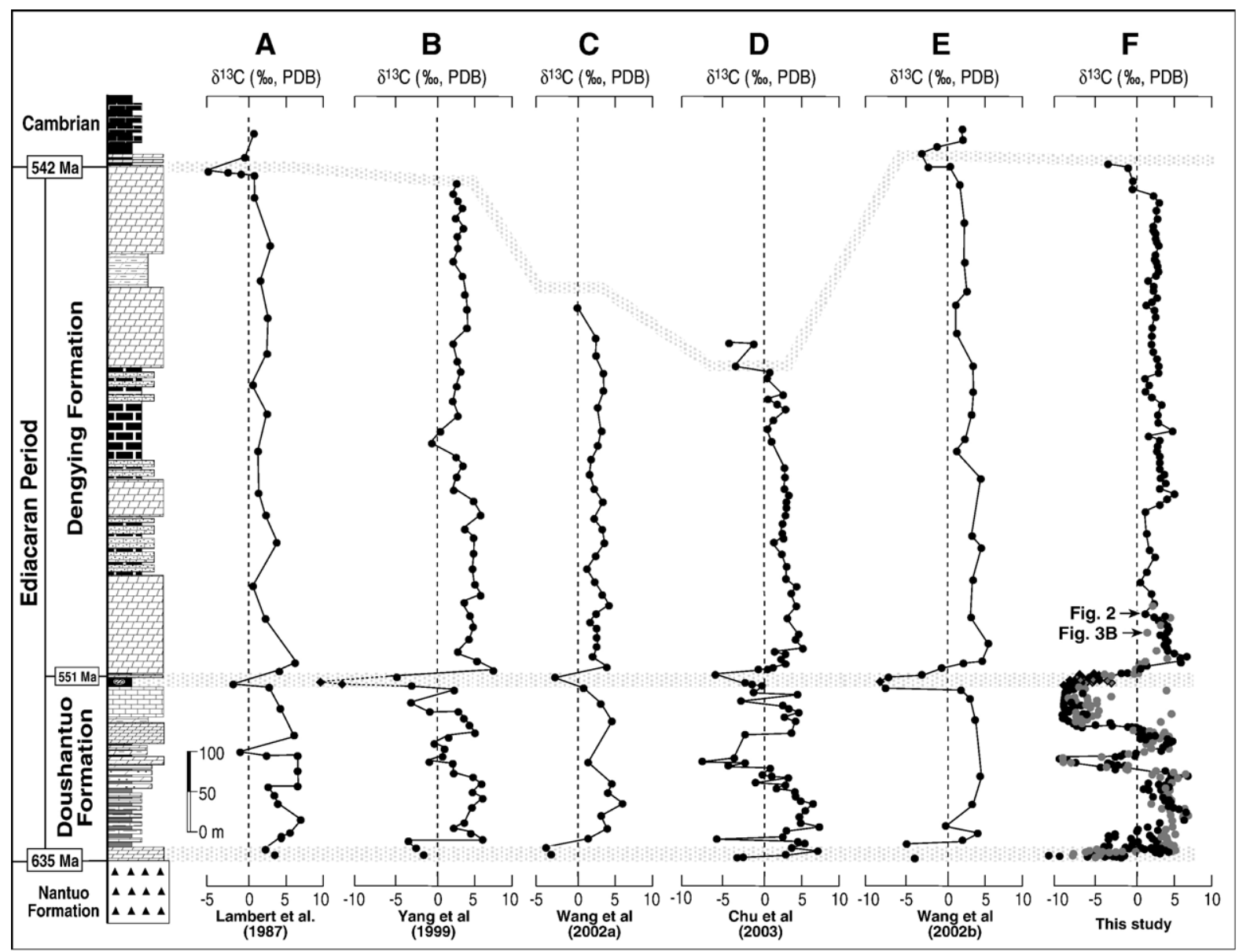

Fig. 9. A comparison of existing $\delta^{13} \mathrm{C}$ profiles in the Yangtze Gorges area from previous studies (A-E) with the results produced in this study (F). Inconsistencies between these profiles draw attention to the need for further evaluation of potential diagenetic overprints and/or stratigraphic completeness in the Doushantuo Formation. 
importantly the inconsistency of $\delta^{13} \mathrm{C}$ data obtained from the Yangtze Gorges area in previous publications (Fig. 9) do not preclude the possibility of local $\delta^{13} \mathrm{C}$ departure from average seawater signature (cf. Patterson and Walter, 1994) or of substantial diagenetic alteration.

The inconsistency of $\delta^{13} \mathrm{C}$ profiles (Fig. 9A-E) may be due in part to insufficient sampling resolution, but positive $\delta^{13} \mathrm{C}$ values immediately below the black shale (a marker horizon across the basin) in some sections contrasts with the predominately negative $\delta^{13} \mathrm{C}$ values obtained in over a 50 meter interval in this study (Fig. 9F). Another possible interpretation involves a hypothetical unconformity immediately below the black shale unit, with significant removal of the $\delta^{13} \mathrm{C}$ anomaly in some sections. However, the relatively conformable contact between the black shale and its underlying limestone (Fig. 10A), the lack of direct evidence for erosion and karstification at the contact, and the overall deep-water facies (Fig. 3) do not favor a subaerial exposure and erosion. In addition, negative $\delta^{13} \mathrm{C}$ data obtained at this level in previous publications are mostly from concretions in black shales (Fig. 10B) or immediately below the shale/limestone contact. While it is possible that these concretions were formed early during burial, they cannot be direct precipitates from seawater. Similar uncertainties exist for the middle Doushantuo Formation. Negative to near zero $\delta^{13} \mathrm{C}$ values were reported in previous studies but no agreement can be drawn from available data. Because the existing profiles in South China were produced by different authors with varying sampling resolution and some sections also involve structural complexity, further evaluation of these sections is needed in order to clarify the significance of such inconsistencies in the Yangtze platform (and other successions globally).

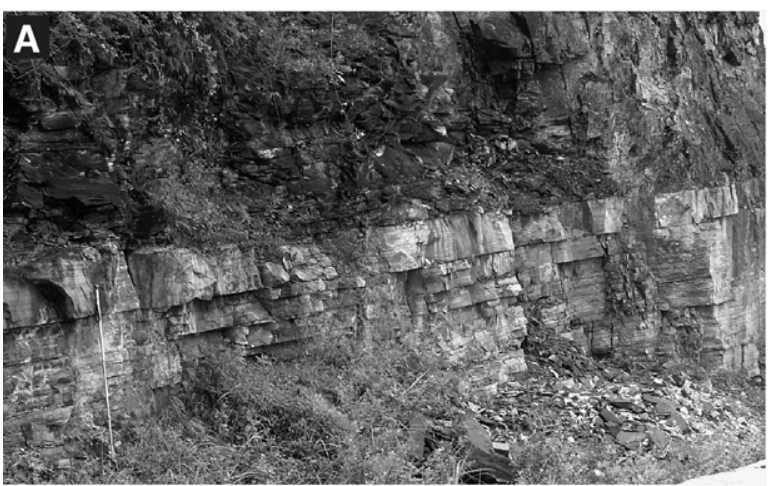

\section{Conclusions}

1. Carbon isotope data obtained across the Ediacaran Yangtze platform $(\sim 635-542 \mathrm{Ma})$ reveal large $\delta^{13} \mathrm{C}$ variability between platform and slope-to-basinal sections. If the obtained $\delta^{13} \mathrm{C}$ values record a signature close to that of the primary seawater, the four negative $\delta^{13} \mathrm{C}$ anomalies at $\sim 635 \mathrm{Ma}$, $\sim 595 \mathrm{Ma}, \sim 551 \mathrm{Ma}$, and $\sim 542 \mathrm{Ma}$ from platform sections represent so far the most complete and bestdated $\delta^{13} \mathrm{C}$ record for the Ediacaran Period that can be used as a reference for future studies.

2. Differences in the $\delta^{13} \mathrm{C}$ records between platform and slope-to-basinal sections may imply a strong $(\geq 10 \%)$ Ediacaran surface-to-deep ocean $\delta^{13} \mathrm{C}$ gradient most likely derived from sulfate reduction in anoxic deep oceans. Long-term deep ocean anoxia/euxinia may have existed, maintained by a large oceanic DOC reservoir.

3. Carbon isotope anomalies in platform carbonates may relate to the non-steady state dynamics of reactive DOC and DIC pools (Rothman et al., 2003). In the presence of a large DOC pool, a relatively smaller surface ocean DIC pool was more vulnerable to isotope change. Enhanced sulfate supply during regressive events may have triggered the remineralization of the oceanic DOC reservoir, followed by downward oxygen penetration and DOC oxidation, providing ${ }^{13} \mathrm{C}$-depleted carbon source for the formation of negative $\delta^{13} \mathrm{C}$ anomalies. Shallowing of the chemocline and upwelling of hydrogen sulfide associated with transgression may have led to photic zone anoxia/euxinia at the end of each negative $\delta^{13} \mathrm{C}$ anomaly, which could be a cause for the extinction of Ediacaran acanthomorphic acritarchs.

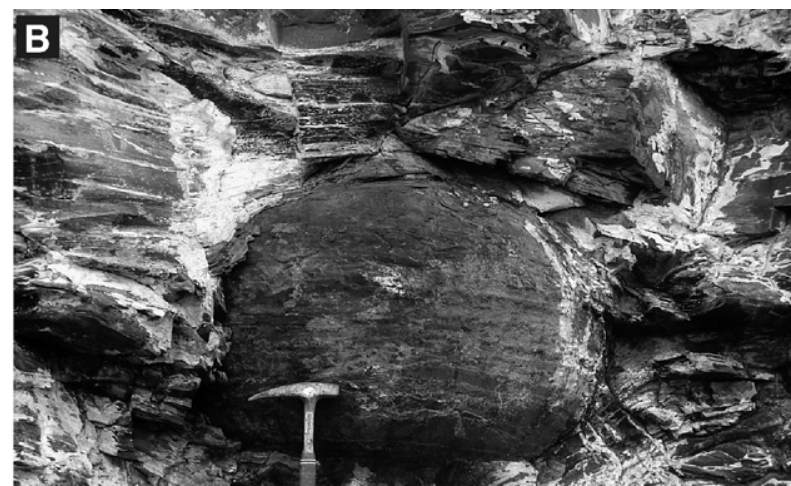

Fig. 10. (A) The sharp contact between the black shale and underlying laminated limestone near the top of the Doushantuo Formation (near the top of $\delta^{13} \mathrm{C}$ anomaly N3 in Figs. 2 and $3 \mathrm{~A}$ ). (B) Limestone concretions within the black shale unit in A. Both $\delta^{13} \mathrm{C}$ and $\delta^{18} \mathrm{O}$ values from these concretions are similar to those from the underlying laminated carbonates (Figs. 2-5). 
4. A non-steady state Ediacaran carbon system may have led to spatial $\delta^{13} \mathrm{C}$ heterogeneity in response to interand intra-basinal chemocline instability, which needs further investigation. Uncertainties in correlating the negative $\delta^{13} \mathrm{C}$ anomalies from South China to other successions and inconsistent $\delta^{13} \mathrm{C}$ profiles reported from previous studies raise questions concerning local departures from the average seawater $\delta^{13} \mathrm{C}$ signature and the potential for diagenetic alteration in South China and in other successions globally.

\section{Acknowledgements}

We thank David D. Mrofka at the University of California, Riverside, and Bruce Vaughn at the University of Colorado for isotope analyses; Martin Kennedy at the University of California, Riverside, for support on a portion of the isotope analysis; and Shuhai Xiao at the Virginia Polytechnic Institute and State University for discussions on the potential relationship between early animals and isotope anomalies. We express our sincere appreciation to Drs. Peggy Delaney (Editor), Carol Dehler, Lee Kump, and an anonymous reviewer, for their careful review and constructive suggestions that significantly improved the paper. The research is supported by the US National Science Foundation (grants EAR 9614070 to $\mathrm{NCB}$ and AJK, EAR0345207 and EAR0345642 to Martin J Kennedy and NCB), the Climate Center of Lamont-Doherty Earth Observatory of Columbia University, the Donors of the Petroleum Research Fund administered by the American Chemical Society (PRF 43382-G8 to GJ), and the National Science Foundation of China (grant 40572019 to S. Zhang).

\section{Appendix A. Supplementary data}

Supplementary data associated with this article can be found, in the online version, at doi:10.1016/j. eps1.2007.07.009.

\section{References}

Amthor, J.E., Grotzinger, J.P., Schroeder, S., Bowring, S.A., Ramezani, J., Martin, M.W., Matter, A., 2003. Extinction of Cloudina and Namacalathus at the Precambrian-Cambrian boundary in Oman. Geology 31, 431-434.

Banner, J.L., Hanson, G.N., 1990. Calculation of simultaneous isotopic and trace element variations during water-rock interaction with applications to carbonate diagenesis. Geochim. Cosmochim. Acta 54, 3123-3137.

Bowring, S.A., Myrow, P.M., Landing, E., Ramezani, J., Grotzinger, J.P., 2003. Geochronological constraints on terminal Proterozoic events and the rise of metazoans. Geophys. Res. Abstr. (EGS, Nice) 5, 13,219 .
Calver, C.R., 2000. Isotope stratigraphy of the Ediacarian (Neoproterozoic III) of the Adelaide rift complex, Australia, and the overprint of water column stratification. Precambrian Res. 100, 121-150.

Christie-Blick, N., 1997. Neoproterozoic sedimentation and tectonics in west-central Utah. In: Link, P.K., Kowallis, B.J. (Eds.), Proterozoic to recent stratigraphy, tectonics and volcanology, Utah, Nevada, southern Idaho and central Mexico. Brigham Young University Geology Studies, vol. 42, Part 1, pp. 1-30.

Christie-Blick, N., Dyson, I.A., von der Borch, C.C., 1995. Sequence stratigraphy and the interpretation of Neoproterozoic Earth history. Precambrian Res. 73, 3-26.

Chu, X., Zhang, Q., Zhang, T., Feng, L., 2003. Sulfur and carbon isotopic variations in Neoproterozoic sedimentary rocks from southern China. Prog. Nat. Sci. 13, 875-880.

Condon, D., Zhu, M., Bowring, S., Wang, W., Yang, A., Jin, Y., 2005. $\mathrm{U}-\mathrm{Pb}$ Ages from the Neoproterozoic Doushantuo Formation, China. Science 308, 95-98.

Corsetti, F.A., Kaufman, A.J., 2003. Stratigraphic investigations of carbon isotope anomalies and Neoproterozoic ice ages in Death Valley, California. Geol. Soc. Amer. Bull. 115, 916-932.

Corsetti, F.A., Kaufman, A.J., 2005. The relationship between the Neoproterozoic Noonday Dolomite and the Ibex Formation: new observations and their bearing on 'snowball Earth'. Earth Sci. Rev. $73,63-78$.

Dehler, C.M., Elrick, M., Bloch, J.D., Crossey, L.J., Karlstrom, K.E., Des Marais, D.J., 2005. High-resolution $\delta^{13} \mathrm{C}$ stratigraphy of the Chuar Group (ca. 770-742 Ma), Grand Canyon: implications for midNeoproterozoic climate change. Geol. Soc. Amer. Bull. 117, 32-45.

Derry, L.A., Kaufman, A.J., Jacobsen, S.B., 1992. Sedimentary cycling and environmental change in the late Proterozoic: evidence from stable and radiogenic isotopes. Geochim. Cosmochim. Acta $56,1317-1329$.

Deuser, W.G., 1970. ${ }^{13} \mathrm{C}$ in Black Sea waters and implications for the origin of hydrogen sulfide. Science 168, 1575-1577.

Fike, D.A., Grotzinger, J.P., Pratt, L.M., Summons, R.E., 2006. Oxidation of the Ediacaran Ocean. Nature 444, 744-747.

Goldberg, T., Poulton, S.W., Strauss, H., 2005. Sulphur and oxygen isotope signatures of late Neoproterozoic to early Cambrian sulphate, Yangtze Platform, China: diagenetic constraints and seawater evolution. Precambrian Res. 137, 223-241.

Grey, K., 2005. Ediacaran palynology of Australia. Mem. Assoc. Australas. Palaeontol. 31, 1-439.

Grotzinger, J.P., Knoll, A.H., 1995. Anomalous carbonate precipitates: is the Precambrian the key to the Permian? Palaios 10, 578-596.

Grotzinger, J.P., Bowring, S.A., Saylor, B.Z., Kaufman, A.J., 1995. Biostratigraphic and geochronologic constraints on early animal evolution. Science 270, 598-604.

Guo, Q., Liu, C., Strauss, H., Goldberg, T., Zhu, M., Pi, D., Wang, J., 2006. Organic carbon isotope geochemistry of the Neoproterozoic Doushantuo Formation, South China. Acta Geol. Sin. 80, 670-683.

Halverson, G.P., Hoffman, P.F., Schrag, D.P., Maloof, A.C., Rice, A.H.N., 2005. Toward a Neoproterozoic composite carbon-isotope record. Geol. Soc. Amer. Bull. 117, 1181-1207.

Hoffman, P.F., Schrag, D.P., 2002. The snowball Earth hypothesis: testing the limits of global change. Terra Nova 14, 129-155.

Hoffman, P.F., Kaufman, A.J., Halverson, G.P., Schrag, D.P., 1998. A Neoproterozoic snowball earth. Science 281, 1342-1346.

Hua, H., Chen, Z., Yuan, X., Zhang, L., Xiao, S., 2005. Skeletogenesis and asexual reproduction in the earliest biomineralizing animal Cloudina. Geology 33, 277-280.

Hurtgen, M.T., Arthur, M.A., Halverson, G.P., 2005. Neoproterozoic sulfur isotopes, the evolution of microbial sulfur species, and the 
burial efficiency of sulfide as sedimentary pyrite. Geology 33, 41-44.

Jacobsen, S.B., Kaufman, A.J., 1999. The Sr, C and O isotopic evolution of Neoproterozoic seawater. Chem. Geol. 161, 37-57.

Jenkins, R.J.F., Cooper, J.A., Compston, W., 2002. Age and biostratigraphy of Early Cambrian tuffs from SE Australia and southern China. J. Geol. Soc. (Lond.) 159, 645-658.

Jiang, G., Christie-Blick, N., Kaufman, A.J., Banerjee, D.M., Rai, V., 2002. Sequence stratigraphy of the Neoproterozoic Infra Krol Formation and Krol Group, Lesser Himalaya, India. J. Sediment. Res. 72, 524-542.

Jiang, G., Kennedy, M.J., Christie-Blick, N., 2003a. Stable isotopic evidence for methane seeps in Neoproterozoic postglacial cap carbonates. Nature 426, 822-826.

Jiang, G., Sohl, L.E., Christie-Blick, N., 2003b. Neoproterozoic stratigraphic comparison of the Lesser Himalaya (India) and Yangtze Block (South China): paleogeographic implications. Geology 31, 917-920.

Jiang, G., Christie-Blick, N., Kaufman, A.J., Banerjee, D.M., Rai, V., 2003c. Carbonate platform growth and cyclicity at a terminal Proterozoic passive margin, Infra Krol Formation and Krol Group, Lesser Himalaya, India. Sedimentology 50, 921-952.

Jiang, G., Kennedy, M.J., Christie-Blick, N., Wu, H., Zhang, S., 2006a. Stratigraphy, sedimentary structures, and textures of the late Neoproterozoic Doushantuo cap carbonate in South China. J. Sediment. Res. 76, 978-995.

Jiang, G., Shi, X., Zhang, S., 2006b. Methane seeps, methane hydrate destabilization, and the late Neoproterozoic postglacial cap carbonates. Chin. Sci. Bull. 51, 1152-1173.

Kaufman, A.J., Knoll, A.H., 1995. Neoproterozoic variations in the Cisotopic composition of seawater; stratigraphic and biogeochemical implications. Precambrian Res. 73, 27-49.

Kaufman, A.J., Hayes, J.M., Knoll, A.H., Germs, G.J.B., 1991. Isotopic compositions of carbonates and organic carbon from upper Proterozoic successions in Namibia; stratigraphic variation and the effects of diagenesis and metamorphism. Precambrian Res. 49, 301-327.

Kaufman, A.J., Jacobsen, S.B., Knoll, A.H., 1993. The Vendian record of $\mathrm{Sr}$ and $\mathrm{C}$ isotopic variations in seawater: implications for tectonics and paleoclimate. Earth Planet. Sci. Lett. 120, 409-430.

Kaufman, A.J., Knoll, A.H., Narbonne, G.M., 1997. Isotopes, ice ages, and terminal Proterozoic earth history. Proc. Natl. Acad. Sci. U. S. A. 94, 6600-6605.

Kaufman, A.J., Jiang, G., Christie-Blick, N., Banerjee, D.M., Rai, V., 2006. Stable isotope record of the terminal Neoproterozoic Krol platform in the Lesser Himalayas of northern India. Precambrian Res. 147, 156-185.

Kaufman, A.J., Corsetti, F.A., Varni, M.A., 2007. The effect of rising atmospheric oxygen on carbon and sulfur isotope anomalies in the Neoproterozoic Johnnie Formation, Death Valley, USA. Chem. Geol. 237, 47-63.

Kendall, B., Anbar, A.D., Gordon, G., Arnold, G.L., Creaser, R.A., 2006. Constraining the redox state of the Proterozoic deep oceans using the Mo isotope systematics of euxinic black shales. Abstr. Programs - Geol. Soc. Am. 38, 56.

Kennedy, M.J., Christie-Blick, N., Sohl, L.E., 2001. Are Proterozoic cap carbonates and isotopic excursions a record of gas hydrate destabilization following Earth's coldest intervals? Geology 29, 443-446.

Kennedy, M., Droser, M., Mayer, L.M., Pevear, D., Mrofka, D., 2006. Late Precambrian oxygenation: inception of the clay mineral factory. Science 311, 1446-1449.
Knoll, A.H., Bambach, R.K., Canfield, D.E., Grotzinger, J.P., 1996. Comparative Earth history and Late Permian mass extinction. Science 273, 452-457.

Kump, L.R., Pavlov, A., Arthur, M.A., 2005. Massive release of hydrogen sulfide to the surface ocean and atmosphere during intervals of oceanic anoxia. Geology 33, 397-400.

Lambert, I.B., Walter, M.R., Zang, W., Lu, S., Ma, G., 1987. Paleoenvironment and carbon isotope stratigraphy of Upper Proterozoic carbonates of the Yangtze platform. Nature 325, 140-142.

Le Guerroue, E., Allen, P.A., Cozzi, A., Etienne, J.L., Fanning, M., 2006. 50 Myr recovery from the largest negative $\delta^{13} \mathrm{C}$ excursion in the Ediacaran ocean. Terra Nova 18, 147-153.

Levy, M., Christie-Blick, N., Link, P.K., 1994. Neoproterozoic incised valleys of the eastern Great Basin, Utah and Idaho: fluvial response to changes in depositional base level. SEPM (Society for Sedimentary Geology) Special Publication, vol. 51, pp. 369-382.

Li, R., Chen, J., Zhang, S., Lei, J., Shen, Y., Chen, X., 1999a. Spatial and temporal variations in carbon and sulfur isotopic compositions of Sinian sedimentary rocks in the Yangtze platform, South China. Precambrian Res. 97, 59-75.

Li, Z.X., Li, X.H., Kinny, P.D., Wang, J., 1999b. The breakup of Rodinia: did it start with a mantle plume beneath South China? Earth Planet. Sci. Lett. 173, 171-181.

Logan, G.A., Hayes, J.M., Hieshima, G.B., Summons, R.E., 1995. Terminal Proterozoic reorganization of biogeochemical cycles. Nature 376, 53-56.

Ma, G., Lee, H., Zhang, Z., 1984. An investigation of the age limits of the Sinian System in south China. Bull. Yichang Inst. Geol. Miner. Resour. 8, 1-29.

Melezhik, V., Fallick, A.E., Pokrovsky, B.G., 2005. Enigmatic nature of thick sedimentary carbonates depleted in ${ }^{13} \mathrm{C}$ beyond the canonical mantle value: the challenges to our understanding of the terrestrial carbon cycle. Precambrian Res. 137, 131-165.

Myrow, P.M., Kaufman, A.J., 1999. A newly discovered cap carbonate above Varanger-age glacial deposits in Newfoundland, Canada. J. Sediment. Res. 69, 784-793.

Patterson, W.P., Walter, L.M., 1994. Depletion of ${ }^{13} \mathrm{C}$ in seawater $\Sigma \mathrm{CO}_{2}$ on modern carbonate platforms: Significance for the carbon isotopic record of carbonates. Geology 22, 885-888.

Rothman, D.H., Hayes, J.M., Summons, R.E., 2003. Dynamics of the Neoproterozoic carbon cycle. Proc. Natl. Acad. Sci. U. S. A. 100, 8124-8129.

Saylor, B.Z., Kaufman, A.J., Grotzinger, J.P., Urban, F., 1998. A composite reference section for terminal Proterozoic strata of southern Namibia. J. Sediment. Res. 68, 1223-1235.

Shen, Y., 2002. C-isotope variations and paleoceanographic changes during the late Neoproterozoic on the Yangtze Platform, China. Precambrian Res. 113, 121-133.

Shen, Y., Schidlowski, M., 2000. New C isotope stratigraphy from Southwest China: implications for the placement of the Precambrian-Cambrian boundary on the Yangtze Platform and global correlations. Geology 28, 623-626.

Shields, G.A., 2005. Neoproterozoic cap carbonates: a critical appraisal of existing models and the plumeworld hypothesis. Terra Nova 17, 299-310.

Shields, G., Kimura, H., Yang, J., Gammon, P., 2004. Sulphur isotopic evolution of Neoproterozoic-Cambrian seawater: new francolitebound sulphate $\delta^{34} \mathrm{~S}$ data and a critical appraisal of the existing record. Chem. Geol. 204, 163-182.

Volkov, I.I., 2000. Dissolved inorganic carbon and its isotopic composition in the waters of anoxic marine basin. Oceanology 40, 499-502. 
Wang, J., Li, Z.-X., 2003. History of Neoproterozoic rift basins in South China: implications for Rodinia break-up. Precambrian Res. 122, 141-158.

Wang, Z., Yin, C., Gao, L., Liu, Y., 2002a. Chemostratigraphic characteristics and correlation of the Sinian stratotype in the eastern Yangtze Gorge area, Hubei province. Geol. Rev. 48, 408-415.

Wang, W., Matsumoto, R., Wang, H., Ohde, S., Kano, A., Mu, X., 2002b. Isotopic chemostratigraphy of the upper Sinian in Three Horges area. Acta Micropaleont. Sin. 19, 382-388.

Xiao, S., 2004. New multicellular algal fossils and acritarchs in Doushantuo chert nodules (Neoproterozoic; Yangtze Gortze area, south China). J. Paleontol. 78, 393-401.

Xiao, S., Yun, Z., Knoll, A.H., 1998. Three-dimensional preservation of algae and animal embryos in a Neoproterozoic phosphorite. Nature 391, 553-558.

Xiao, S., Yuan, X., Steiner, M., Knoll, A.H., 2002. Macroscopic carbonaceous compressions in a terminal Proterozoic shale: a systematic reassessment of the Miaohe biota, South China. J. Paleontol. 76, 347-376.

Xiao, S., Bao, H., Wang, H., Kaufman, A.J., Zhou, C., Li, G., Yuan, X., Ling, H., 2004. The Neoproterozoic Quruqtagh Group in eastern Chinese Tianshan: evidence for a post-Marinoan glaciation. Precambrian Res. 130, 1-26.

Xiao, S., Shen, B., Zhou, C., Xie, G., Yuan, X., 2005. A uniquely preserved Ediacaran fossil with direct evidence for a quilted bodyplan. Proc. Natl. Acad. Sci. U. S. A. 102, 10227-10232.

Xiao, S., Hagadorn, J.W., Zhou, C., Yuan, X., 2007. Rare helical spheroidal fossils from the Doushantuo Lagerstätte: Ediacaran animal embryos come of age? Geology 35, 115-118.
Yang, J., Sun, W., Wang, Z., Xue, Y., Tao, X., 1999. Variations in Sr and $\mathrm{C}$ isotopes and $\mathrm{Ce}$ anomalies in successions from China: evidence for the oxygenation of Neoproterozoic seawater? Precambrian Res. 93, 215-233.

Yin, C., Liu, D., Gao, L., Wang, Z., Xing, Y., Jian, P., Shi, Y., 2003. Lower boundary age of the Nanhua System and the Gucheng glacial stage: evidence from SHRIMP II dating. Chin. Sci. Bull. 48, 1657-1662.

Yin, L., Zhu, M., Knoll, A.H., Yuan, X., Zhang, J., Hu, J., 2007. Doushantuo embryos preserved inside diapause egg cysts. Nature 446, 661-663.

Zhang, Y., Yin, L., Xiao, S., Knoll, A.H., 1998. Permineralized fossils from the terminal Proterozoic Doushantuo Formation, south China. Paleontol. Soc. Mem. 50, 1-52.

Zhang, S., Jiang, G., Zhang, J., Song, B., Kennedy, M.J., ChristieBlick, N., 2005. U-Pb sensitive high-resolution ion microprobe ages from the Doushantuo Formation in south China: constraints on late Neoproterozoic glaciations. Geology 33, 473-476.

Zhou, C., Xiao, S., 2007. Ediacaran $\delta^{13} \mathrm{C}$ chemostratigraphy of South China. Chem. Geol. 237, 89-108.

Zhou, C., Zhang, J., Li, G., Yu, Z., 1997. Carbon and oxygen isotopic record of the Early Cambrian from the Xiaotan Section, Yunnan, South China. Sci. Geol. Sin. 32, 201-211.

Zhou, C., Tucker, R., Xiao, S., Peng, Z., Yuan, X., Chen, Z., 2004. New constraints on the ages of Neoproterozoic glaciations in south China. Geology 32, 437-440.

Zhou, C., Xie, G., McFadden, K., Xiao, S., Yuan, X., 2007. The diversification and extinction of Doushantuo-Pertatataka acritarchs in South China: causes and biostratigraphic significance. Geol. J. 42, 229-262. 